Article

\title{
Characterization for Drought Tolerance and Physiological Efficiency in Novel Cytoplasmic Male Sterile Sources of Sunflower (Helianthus annuus L.)
}

\author{
Vikrant Tyagi ${ }^{1}$, Satwinder Kaur Dhillon ${ }^{1}$, Prashant Kaushik ${ }^{2, *}$ and Gurpreet Kaur ${ }^{1}$ \\ 1 Department of Plant Breeding and Genetics, Punjab Agricultural University, Ludhiana 141004, India; \\ vikrant@pau.edu (V.T.); sklb-pbg@pau.edu (S.K.D.); gurpreetkaur@pau.edu (G.K.) \\ 2 Instituto de Conservación y Mejora de la Agrodiversidad Valenciana, Universitat Politècnica de València, \\ 46022 Valencia, Spain \\ * Correspondence: prakau@doctor.upv.es; Tel.: +34-963-877000
}

Received: 11 September 2018; Accepted: 17 October 2018; Published: 19 October 2018

\begin{abstract}
Sunflower is sensitive to drought, and furthermore, sunflower hybrids display limited cytoplasmic diversity. In addition, the wild cytoplasmic sources of sunflower are not well explored for their potential to introduce drought tolerance into newly developed hybrids. Therefore here, we carried out a Line $\times$ Tester-based genetic study using 19 sunflower genotypes representing, 13 cytoplasmic male sterile (CMS) lines from wild and conventional sources, 2 maintainer lines, and 4 restorer lines. The CMS and maintainer lines were crossed with restorer lines to develop sixty F1 hybrids. The parents and their hybrids were evaluated under two water regimes, normal irrigation and drought stress (i.e., withholding water). A total of twelve important plant descriptors were studied over a period of two years and the significant differences between parents and hybrids are reported here. More specifically, hybrid lines were higher in average values for all the descriptors. The contribution of female parent was more prominent in the expression of traits in hybrids as compared to male parents. The CMS sources varied significantly regarding seed yield per plant and other physiological traits. Proline content in the leaves of all the genotypes was three times higher in the water stress regime. Accession CMS-PKU-2A was identified as the best general combiner for leaf area and specific leaf weight., whereas CMS-234A was the best general combiner for biological yield and photosynthetic efficiency under both conditions. The cross combinations CMS-ARG-2A $\times$ RCR-8297, CMS-234A $\times$ P124R, and CMS-38A $\times$ P124R were found significant for biological yield, seed yield and oil content under both environments. Overall, this study provides useful information about the cytoplasmic effects on important sunflower traits and drought stress tolerance.
\end{abstract}

Keywords: sunflower; cytoplasmic male sterility; combining ability; drought; water stress

\section{Introduction}

Sunflower (Helianthus annuus L.) is a commercially important oilseed crop with its oil comparable to virgin oil olive for health promoting benefits $[1,2]$. Botanically, sunflower is a cross-pollinating and self-incompatible plant [3]. Moreover, sunflower out crosses freely with its wild relatives [4]. During the past few decades, the area and production of sunflower have increased because of its day length neutrality, a wider adaptability, and responsiveness to added inputs [5]. Similarly, these attributes of sunflower provide a sustainable crop production system when sunflower is used in rotation with other cropping species [6]. The central component of sunflower breeding is the development of hybrids via classical cytoplasmic male sterility (CMS) breeding approach [7]. CMS is the absence of fertile pollen in the plant and this eliminates the need for manual emasculation for the development of a successful 
cross combination. Furthermore, the CMS-based approach has been extensively used throughout the plant kingdom and well exploited for achieving yield targets, disease resistance, and drought tolerance [8-10].

In sunflower, the CMS system was initially discovered in the 1970s [11], and in the following year, the fertility restoration genotype was next identified [12]. The hybrid system based on a CMS is commonly comprised of a three-line system: the male sterile genotype (A line), which is maintained by the maintainer line, the B line with a fertile cytoplasm, and a restorer line ( $\mathrm{R}$ line), a plant line that allows for the recovery of male fertility in the hybrids via the expression of dominant fertility restorer genes $[8,13]$. Earlier efforts of sunflower breeders using this system have resulted in production output and quality in sunflower $[14,15]$. Drought is one of the biggest challenges to crop production in the 21st century and sunflower is not an exception to drought stress [16]. The yield losses due to drought are prominent in sunflower [17,18]. In particular, the exposure during anthesis and dough stages can result in up to $80 \%$ crop losses [19]. Wild relatives of cultivated sunflower represent a potential source of important genes for the drought tolerance [20]. The genus Helianthus has sufficient diversity, with around 51 species and 19 subspecies comprising the genus [21]. The characterization of the genotypes based on relative water content, leaf water potential, photosynthetic efficiency, and proline content are pivotal to any water stress screening experiment [22,23]. The amino acid, proline, plays a crucial role in osmotic adjustments and also in free radical scavenging under drought stress. Osmotic adjustments are important for the plant to undergo a smaller change in relative water content even with a decrease in water potential. This primarily aids the plant in continuing cell enlargement and growth, even during periods of drought stress. Therefore, proline accumulation in drought-stressed sunflower is considered an important indicator of the stressed lines drought tolerance [24].

In modern sunflower hybrids, the CMS PET-1 plant line is the most common source of cytoplasm genome [7]. This homogeny in the cytoplasm of most of the modern hybrids may actually result in extreme yield losses as happened in other crops such as maize $[25,26]$. To avoid such an unwanted outcome in sunflower, the necessity of diversification in the CMS source is inevitable. Consequently, to diversify the cytoplasmic base, attempts have been made and several new cytoplasmic sources have been identified [27]. Furthermore, in some instances, the negative effects of cytoplasmic and nuclear genome interaction resulted in the reduced chlorophyll content and photosynthetic efficiency [28]. In contrast, a positive effect of nucleus and cytoplasm interaction has also been reported for oil content [29]. Therefore, the influence of cytoplasmic effects on important agronomic traits needs to be understood more precisely.

Previously, using only molecular diversity-based criterion a study consisting of 28 CMS lines was as carried out [30]. However, an extensive study on drought tolerance, trait performance, and correlation among these traits is currently lacking. Therefore, here, we used the 13 CMS lines (A lines) and 2 maintainer lines (B lines) and crossed these with 4 restorer lines ( $R$ lines) to generate 60 one-way F1 hybrids. These 60 hybrids were produced with a Line $\times$ Tester matting design to obtain detailed information regarding general and specific combiners along with gene actions involved [31,32]. The parents and their hybrids were evaluated under normally irrigated and water stressed conditions for a 2-year period.

\section{Results}

\subsection{Variation in Parents and Their Hybrids}

In the Unweighted Pair Group Method with Arithmetic Mean (UPGMA) analysis, more similar individuals are grouped together in the same cluster [33]. The cluster analysis showed that the accession of alloplasmic line CMS-XA was distinct from the rest of the accessions (Figure 1). In addition, UPGMA analysis clustered six other alloplasmic lines together and three of the four tester lines are clustered together (Figure 1). 
There were highly significant differences $(p<0.05)$ for the mean values of groups of parents and hybrids (normal and water stress environment), for all of the 12 descriptors studied (Table 1). Parent and their hybrid combinations performed better under normal conditions than under drought stress (Table 1). In addition, hybrids were determined to have more leaves, higher harvest index, seed yield, and oil content, than the assessed parental lines. Interesting, parents and hybrids overlapped with each other with respect to their harvest index and proline content under drought stress (Table 1). More specifically, the proline content was determined to be almost three times higher in water-limited cultivated plants, compared to the non-stressed controls, whereas, photosynthetic efficiency remained unchanged in normal and drought stressed plants (Table 1).

\section{Cluster Dendrogram}

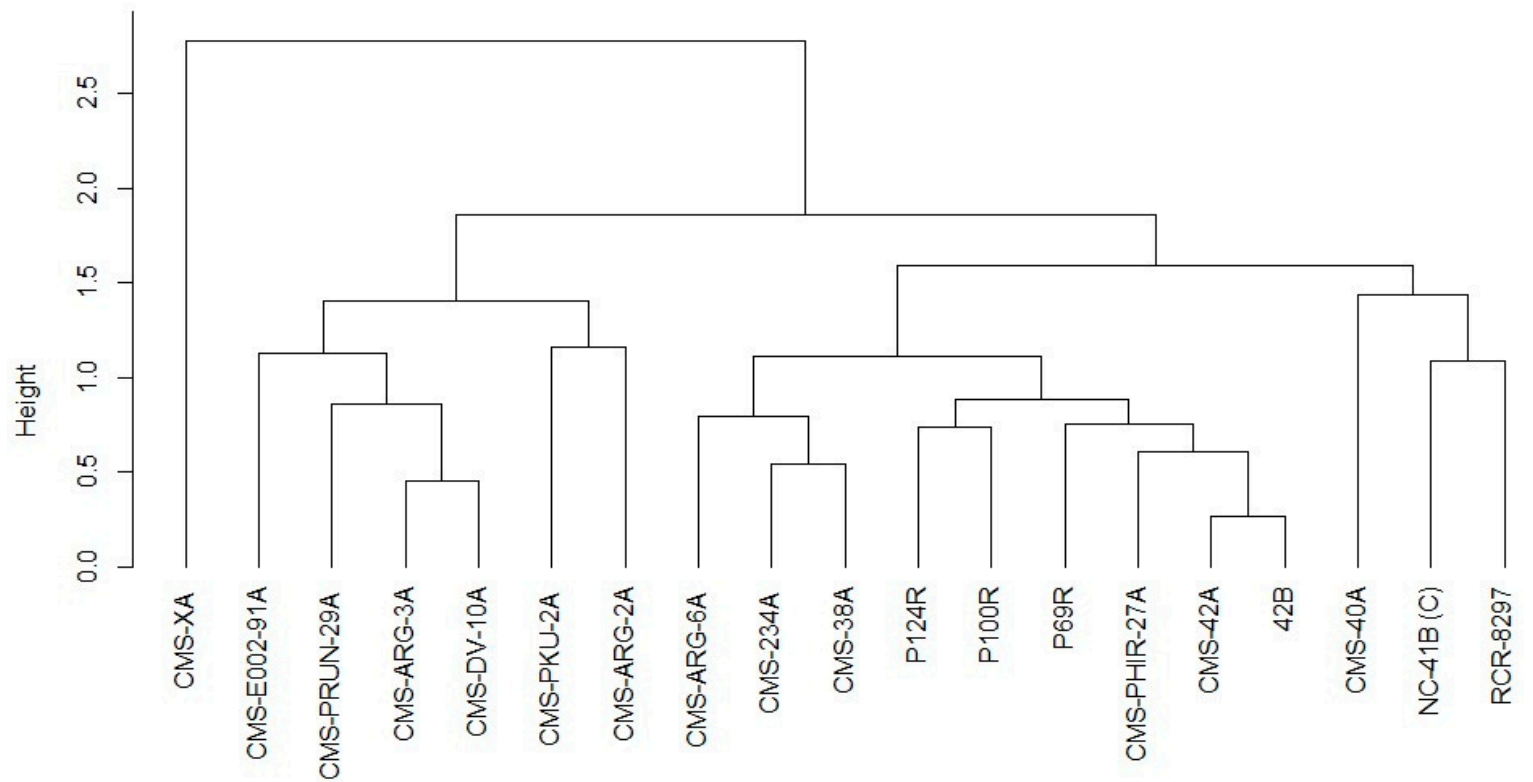

Figure 1. Unweighted Pair Group Method with Arithmetic Mean (UPGMA) clustering of parental genotypes into groups based on log-normalized descriptors values. The cophenetic correlation coefficient of clustering is 0.8 .

The analysis of variance for combining abilities of the twelve descriptors studied in a line $\times$ tester $(15 \times 4)$ design is presented in Table 2 . The mean squares due to treatments were highly significant for all the traits except for the proline content (Table 2). Likewise, the mean squares due to lines (female), testers (males), and female $\times$ male interactions were recorded highly significant for all the traits under both the environments and also, over the years (Table 2). Parentals and their hybrids had a highly significant $(p \leq 0.01)$ general combining ability (GCA) and specific combining ability (SCA) effects, for all the traits and under both growth conditions (Table 2). The ratios of GCA/SCA effect were $>0.5$ for biological yield and oil content under normal water environment, while under water stress environment leaf water potential, photosynthetic efficiency and harvest index, suggesting the predominance of additive over non-additive genetic effects. This ratio was $<0.5$ for most of the traits assessed under both growth conditions, implying a significant role of non-additive genetic effect on these traits (Table 2).

The proportional contribution of parent and their interactions, the contribution of female parents were observed to be higher compared to male tester lines irrespective of the growth conditions (Table 2). However, their overall interaction component (lines $\times$ testers) had a higher proportional contribution for the assessed traits, including leaf area, specific leaf weight, leaf area index, leaf water potential, relative leaf water content, proline content, seed yield, harvest index and oil content (Table 2). 
Table 1. Variation of parameters under normal and water stress environment.

\begin{tabular}{|c|c|c|c|c|c|c|}
\hline Descriptors & Parent $(n=19)$ & Parent Stress & Hybrid $(n=60)$ & Hybrid Stress & F-Ratio & Probability \\
\hline & Mean a & Mean a & Mean a & Mean a & & \\
\hline & (Range) & (Range) & (Range) & (Range) & & \\
\hline \multirow[t]{2}{*}{ Number of leaves } & $22.31 \mathrm{~b}$ & $19.50 \mathrm{a}$ & $24.65 \mathrm{~b}$ & $24.10 \mathrm{~b}$ & 9.61 & $<0.001$ \\
\hline & $(20.55-24.05)$ & $(17.75-21.25)$ & $(23.66-25.64)$ & $(23.11-25.08)$ & & \\
\hline \multirow[t]{2}{*}{ Leaf area $\left(\mathrm{m}^{2}\right)$} & $0.62 \mathrm{~b}$ & $0.57 \mathrm{ab}$ & $0.53 \mathrm{a}$ & $0.45 \mathrm{ab}$ & 3.98 & 0.0092 \\
\hline & $(0.52-0.72)$ & $(0.47-0.67)$ & $(0.47-0.58)$ & $(0.39-0.50)$ & & \\
\hline \multirow[t]{2}{*}{ Specific leaf weight $(\mathrm{g})$} & $1.48 \mathrm{c}$ & $1.38 \mathrm{bc}$ & $1.15 \mathrm{ab}$ & $1.00 \mathrm{a}$ & 5.86 & 0.008 \\
\hline & $(1.25-1.71)$ & $(1.16-1.62)$ & $(1.02-1.28)$ & $(0.87-1.13)$ & & \\
\hline \multirow[t]{2}{*}{ Leaf area index } & $3.41 \mathrm{~b}$ & $2.98 \mathrm{ab}$ & $2.92 \mathrm{ab}$ & $2.45 \mathrm{a}$ & 3.82 & 0.0113 \\
\hline & $(2.88-3.95)$ & $(2.45-3.15)$ & $(2.62-3.22)$ & $(2.15-2.75)$ & & \\
\hline \multirow[t]{2}{*}{ Leaf water potential (MPa) } & $-2.38 b$ & $-2.83 \mathrm{a}$ & $-2.23 b$ & $-2.93 \mathrm{a}$ & 48.7 & $<0.001$ \\
\hline & $(-2.32-(-2.15))$ & $(-3.01-(-2.84))$ & $(-2.53-(-2.23))$ & $(-2.98-(-2.68))$ & & \\
\hline \multirow[t]{2}{*}{ Relative leaf water content (\%) } & $68.52 c$ & $55.10 \mathrm{a}$ & $65.97 c$ & $60.90 \mathrm{~b}$ & 10.29 & $<0.001$ \\
\hline & $(64.40-72.65)$ & $(50.97-59.23)$ & $(63.65-68.30)$ & $(58.56-63.21)$ & & \\
\hline \multirow[t]{2}{*}{ Photosynthetic efficiency } & $36.60 \mathrm{a}$ & $36.41 \mathrm{a}$ & $35.58 \mathrm{a}$ & $34.36 \mathrm{a}$ & 2.76 & 0.0439 \\
\hline & $(34.92-38.25)$ & $(34.74-38.08)$ & $(34.65-36.52)$ & $(33.43-35.30)$ & & \\
\hline \multirow[t]{2}{*}{ Proline content (mg/g of dw) } & $0.47 \mathrm{a}$ & $1.58 \mathrm{~b}$ & $0.46 \mathrm{a}$ & $1.51 \mathrm{~b}$ & 284.68 & $<0.001$ \\
\hline & $(0.36-0.57)$ & $(1.48-1.68)$ & $(0.40-0.52)$ & $(1.45-1.57)$ & & \\
\hline \multirow[t]{2}{*}{ Biological yield } & $310.05 \mathrm{~b}$ & 204.57 a & $329.97 \mathrm{~b}$ & $323.65 \mathrm{~b}$ & 38.67 & $<0.001$ \\
\hline & $(82.01-628.33)$ & $(52.17-522.33)$ & $(139.17-758.33)$ & $(136.70-678.02)$ & & \\
\hline \multirow[t]{2}{*}{ Harvest index } & $10.68 \mathrm{a}$ & $17.81 \mathrm{~b}$ & $19.66 \mathrm{~b}$ & $17.97 \mathrm{~b}$ & 9.63 & $<0.001$ \\
\hline & $(7.80-13.57)$ & $(14.93-20.70)$ & $(18.04-21.28)$ & $(18.03-19.60)$ & & \\
\hline \multirow[t]{2}{*}{ Seed yield/Plant (g) } & $25.88 \mathrm{a}$ & $25.07 \mathrm{a}$ & $52.90 \mathrm{c}$ & $40.81 \mathrm{~b}$ & 81.83 & $<0.001$ \\
\hline & $(22.05-29.72)$ & $(21.23-28.90)$ & $(50.74-55.06)$ & $(38.66-42.97)$ & & \\
\hline \multirow[t]{2}{*}{ Oil content $(\%)$} & $29.38 \mathrm{~b}$ & $27.30 \mathrm{a}$ & $31.23 \mathrm{c}$ & $30.61 \mathrm{bc}$ & 12.47 & $<0.001$ \\
\hline & $(28.22-30.54)$ & (26.13-28.45) & $(30.57-31.88)$ & $(29.96-31.26)$ & & \\
\hline
\end{tabular}

The alphabet $(\mathrm{a}, \mathrm{b}, \mathrm{c}$ etc.) show significant differences based on the Student-Newman-Keuls test. 
Table 2. Analysis of variance for combining abilities i.e., general combining ability (GCA), and specific combining ability (SCA) for twelve traits in sunflower across two environments i.e., non-stressed (N) and stressed (S) environment.

\begin{tabular}{|c|c|c|c|c|c|c|c|c|c|c|c|c|c|c|c|c|c|}
\hline $\begin{array}{l}\text { Source of } \\
\text { Variation }\end{array}$ & Treatments & Years & Replications/Years & Females & Males & $\begin{array}{c}\text { Female (F) } \times \\
\text { Male (M) } \\
\end{array}$ & $\begin{array}{c}\text { Female } \times \\
\text { Years }\end{array}$ & $\begin{array}{c}\text { Male } \times \\
\text { Years }\end{array}$ & $\begin{array}{c}F \times M \times \\
\text { Years }\end{array}$ & Error & $\begin{array}{c}\sigma^{2} \text { Female } \\
x \text { Males } \\
\text { (SCA) }\end{array}$ & $\begin{array}{l}\sigma^{2} \\
G C A \\
\end{array}$ & $\begin{array}{c}\sigma^{2} \\
G C A / \sigma^{2} \\
S C A \\
\end{array}$ & $\begin{array}{c}\text { Contribution } \\
\text { of Lines }\end{array}$ & $\begin{array}{c}\text { Contribution } \\
\text { Testers }\end{array}$ & $\begin{array}{c}\text { Contribution } \\
\text { of Lines } x \\
\text { Testers } \\
\end{array}$ & \\
\hline $\begin{array}{l}\text { Degree of } \\
\text { freedom }\end{array}$ & 78 & 1 & 4 & 14 & 3 & 42 & 14 & 3 & 42 & 236 & & & & & & & \\
\hline \multirow{2}{*}{$\begin{array}{c}\text { Number of } \\
\text { leaves }\end{array}$} & $\mathrm{N}^{\mathrm{a}}$ & $30.52^{\text {** }}$ & $105.31^{\text {** }}$ & $23.87^{* *}$ & $257.30^{* *}$ & 74.06 ** & $36.16^{* *}$ & $57.45^{* *}$ & 50.58 ** & 22.18 & 0.78 & 4.66 & 1.71 & 0.37 & 67.42 & 4.16 & 28.42 \\
\hline & $\mathrm{S}^{\mathrm{b}}$ & $34.63^{* *}$ & $1985.12 * *$ & $94.54 * *$ & $255.88 * *$ & $39.75^{* *}$ & $35.94 * *$ & $77.20^{* *}$ & $37.75^{\text {** }}$ & $19.82^{* *}$ & 1.76 & 5.38 & 1.3 & 0.24 & 68.74 & 2.29 & 28.97 \\
\hline \multirow{2}{*}{ Leaf area } & $\mathrm{N}$ & $0.10^{* *}$ & $1.85^{* *}$ & $0.01^{* *}$ & $0.28^{* *}$ & $0.15^{* *}$ & 0.16 ** & $0.06 *$ & $0.02 * *$ & 0.03 & 0.002 & 0.04 & 0.01 & 0.02 & 35.83 & 4.18 & 59.99 \\
\hline & $\mathrm{s}$ & $0.10^{* *}$ & $2.26^{* *}$ & $0.01^{* *}$ & 0.22 ** & $0.12^{* *}$ & $0.13^{* *}$ & $0.04^{* *}$ & $0.09^{* *}$ & $0.05^{* *}$ & 0.002 & 0.03 & 0.01 & 0.02 & 34.89 & 3.98 & 61.13 \\
\hline \multirow{2}{*}{$\begin{array}{c}\text { Specific leaf } \\
\text { weight }\end{array}$} & $\mathrm{N}$ & $0.62^{* *}$ & 0.55 ** & $0.17^{* *}$ & $0.83^{* *}$ & $0.67^{* *}$ & $0.68^{* *}$ & $0.46 * *$ & 0.20 ** & 0.16 & 0.01 & 0.17 & 0.01 & 0.01 & 27.52 & 4.71 & 67.77 \\
\hline & $\mathrm{s}$ & 0.52 ** & $0.94^{* *}$ & $0.26^{* *}$ & $0.74^{* *}$ & $0.64^{* *}$ & $0.47^{* *}$ & 0.40 ** & $0.14^{* *}$ & $0.19 * *$ & 0.01 & 0.09 & 0.01 & 0.03 & 32.47 & 6.04 & 61.49 \\
\hline \multirow{2}{*}{$\begin{array}{l}\text { Leaf area } \\
\text { index }\end{array}$} & $\mathrm{N}$ & $3.29 * *$ & $57.12^{\text {** }}$ & $0.52^{* *}$ & 8.59 ** & $4.24^{* *}$ & $4.79 * *$ & $1.67 * *$ & $0.95 * *$ & 0.82 & 0.05 & 1.32 & 0.02 & 0.02 & 36 & 3.81 & 60.19 \\
\hline & $\mathrm{s}$ & $2.79 * *$ & 47.22 ** & $0.25^{* *}$ & $6.36 * *$ & $3.62^{* *}$ & $3.78^{* *}$ & $1.55^{* *}$ & $0.96^{* *}$ & $0.81^{* *}$ & 0.06 & 0.99 & 0.01 & 0.01 & 34.44 & 4.2 & 61.37 \\
\hline \multirow{2}{*}{$\begin{array}{c}\text { Leaf water } \\
\text { potential }\end{array}$} & $\mathrm{N}$ & $0.17^{* *}$ & $0.14^{* *}$ & $0.17^{* *}$ & $0.52^{*}$ & $0.78^{* *}$ & $0.46 * *$ & $0.05 *$ & 0.04 & 0.05 & 0.02 & 0.14 & 0.01 & 0.02 & 24.94 & 8.08 & 66.99 \\
\hline & $\mathrm{s}$ & $0.28^{* *}$ & 0.07 ** & $0.34^{* *}$ & 1.01 ** & 1.17 ** & $0.61^{* *}$ & $0.31^{* *}$ & 1.77 ** & $0.64 * *$ & 0.005 & 0.01 & 0.03 & 3 & 32.72 & 8.1 & 59.18 \\
\hline \multirow{2}{*}{$\begin{array}{c}\text { Relative leaf } \\
\text { water content }\end{array}$} & $\mathrm{N}$ & $168.79^{* *}$ & $393.38^{* *}$ & $22.93^{* *}$ & $742.36^{* *}$ & 311.75 ** & 340.78 ** & $29.29 * *$ & $22.30^{* *}$ & 29.56 & 1.76 & 103.74 & 3.33 & 0.03 & 40.53 & 3.65 & 55.82 \\
\hline & $\mathrm{s}$ & $208.61^{* *}$ & $652.04^{* *}$ & $16.52^{* * *}$ & $716.68^{* *}$ & 367.48 ** & $595.45^{* *}$ & $17.80^{* *}$ & $6.86^{*}$ & $29.59^{* *}$ & 2.3 & 188.62 & 0.63 & 0.003 & 27.76 & 3.05 & 69.19 \\
\hline \multirow{2}{*}{$\begin{array}{c}\text { Photosynthetic } \\
\text { efficiency }\end{array}$} & $\mathrm{N}$ & $32.40^{* *}$ & $37.13^{* *}$ & $45.97^{* *}$ & $184.11^{* *}$ & 236.07 ** & $75.06^{* *}$ & $43.92^{\text {** }}$ & 44.96 ** & $47.97 *$ & 1.92 & 9.03 & 2.43 & 0.27 & 40.03 & 11 & 48.97 \\
\hline & $\mathrm{s}$ & $24.87^{* *}$ & $554.63^{* *}$ & 191.26 ** & $82.64^{* *}$ & $147.14^{* *}$ & $26.99 * *$ & $30.69^{* *}$ & $51.69 * *$ & $32.93 * *$ & 2.01 & 1.98 & 1.39 & 0.7 & 42.35 & 16.16 & 41.5 \\
\hline \multirow{2}{*}{$\begin{array}{l}\text { Proline } \\
\text { content }\end{array}$} & $\mathrm{N}$ & 0.01 & $1.74^{* *}$ & $0.09 * *$ & $0.07^{* *}$ & 0.06 ** & $0.05^{* *}$ & $0.06^{* *}$ & $0.06^{* *}$ & $0.04^{* *}$ & 0.001 & 0.01 & 0.01 & 0.02 & 30.73 & 6.32 & 62.94 \\
\hline & $\mathrm{s}$ & 0.2 & $0.08 * *$ & $0.01 *$ & 0.74 ** & 0.35 ** & 0.50 ** & $0.71^{* *}$ & $0.30^{* * *}$ & $0.48^{* * *}$ & 0.002 & 0.01 & 0.01 & 0.03 & 31.75 & 3.20 & 65.05 \\
\hline \multirow{2}{*}{$\begin{array}{c}\text { Biological } \\
\text { yield }\end{array}$} & $\mathrm{N}$ & $32,121.15$ ** & $2,554,378.00 * *$ & 717.17 & $53,416.76 * *$ & $64,517.33 * *$ & $62,683.68 * *$ & $61,534.31$ ** & $84,260.41$ ** & $30,359.24^{* *}$ & 411.59 & $10,774.82$ & 811.48 & 0.08 & 20.92 & 5.42 & 73.66 \\
\hline & $\mathrm{s}$ & $24,228.56$ ** & $1,858,552.00 * *$ & 536.71 & $62,167.62$ ** & $150,506.50$ ** & $53,274.99 * *$ & $43,248.35$ ** & $142,227.60^{* *}$ & $43,642.73^{* *}$ & 826.16 & 3210.75 & 69.59 & 0.02 & 24.45 & 12.69 & 62.86 \\
\hline \multirow{2}{*}{$\begin{array}{l}\text { Harvest } \\
\text { index }\end{array}$} & $\mathrm{N}$ & $85.23^{* *}$ & $5505.00 * *$ & $22.09 * *$ & $56.11^{* *}$ & 320.93 ** & $160.21^{* *}$ & 153.45 ** & 166.44 ** & 108.69 ** & 2.94 & 17.17 & 0.40 & 0.02 & 9.27 & 11.36 & 79.38 \\
\hline & $\mathrm{s}$ & $110.82^{* *}$ & $7137.38^{* *}$ & 6.76 & $323.99^{* *}$ & 640.69 ** & $122.05^{* *}$ & 206.76 ** & 274.21 & $101.06 * *$ & 5.56 & 7.00 & 3.87 & 0.55 & 39.16 & 16.59 & 44.25 \\
\hline \multirow{2}{*}{ Seed yield } & $\mathrm{N}$ & $419.17^{* *}$ & $2961.48^{* *}$ & $88.81^{* *}$ & $543.29 * *$ & $976.08^{* *}$ & $379.31^{* *}$ & 145.52 ** & $343.09 * *$ & $149.26^{* *}$ & 13.03 & 76.68 & 5.00 & 0.07 & 28.74 & 11.06 & 60.2 \\
\hline & $\mathrm{s}$ & $239.13^{* *}$ & $372.00^{* * *}$ & 30.93 & $841.16^{* *}$ & $158.49 * *$ & $338.09^{* *}$ & $189.12^{* *}$ & 693.05 ** & $130.24^{* *}$ & 13.3 & 69.28 & 2.61 & 0.04 & 44.52 & 1.80 & 53.68 \\
\hline \multirow{2}{*}{ Oil content } & $\mathrm{N}$ & $8.68^{*}$ & 456.52 ** & $1.14^{* *}$ & $27.63^{* *}$ & $18.94^{* *}$ & $16.63^{* *}$ & $17.34^{* *}$ & $3.20^{* *}$ & $17.61^{* *}$ & 0.14 & 0.33 & 0.24 & 0.73 & 33.86 & 4.98 & 61.16 \\
\hline & $\mathrm{s}$ & $15.43^{* *}$ & $39.43^{* *}$ & $0.54 * *$ & $79.32^{* *}$ & $12.92^{* *}$ & $32.99 * *$ & $41.69 * *$ & $15.71^{* *}$ & $39.02 * *$ & 0.16 & 2.01 & 0.41 & 0.2 & 43.81 & 1.53 & $\begin{array}{r}54.66 \\
\end{array}$ \\
\hline
\end{tabular}

$\mathrm{a}, \mathrm{b}$ represents non-stressed and stressed environments, ${ }^{*}$ represent $p<0.05$ and ${ }^{* *}$ represents $p<0.01$. 


\subsection{Combining Ability Estimates}

The estimates for the general combining ability (GCA) of the parental genotypes (19) under normal and drought stress conditions for all 12 plant descriptors is provided in Table 3 . The detailed estimates of specific combining ability (SCA) effects of hybrids for the all the traits under the two different water regimes are presented in supplementary material Table S1.

\subsubsection{Number of Leaves per Plant}

For number of leaves per plant the female parent CMS-ARG-6A was determined highly significant with respect to GCA effects (2.33 and 1.99) under both growth regimes and it belongs to wild species H. argophyllus Torr. \& A.Gray (Table 3). Whereas, among the male parents (testers) RCR-8297 was determined to be the best general combiner (0.26) under the normal environment, while line P69R was determined to be the best general combiner under either growth conditions (1.09 for normal growth and 0.96 for water stress) (Table 3). Among the sixty hybrid lines assessed, twenty-five hybrids were determined to have significant positive SCA effects under the normal growth regime; whereas, under the stress growth regime, twenty-one hybrids recorded high and positive SCA effects (Table S1). The top three common hybrids combinations which recorded highly significant SCA effects under both the environments are CMS-38A $\times$ RCR-8297, CMS-ARG-6A $\times$ P124R, and CMS-40A $\times$ P124R (Table 4).

\subsubsection{Leaf Area $\left(\mathrm{m}^{2}\right)$}

Two CMS analogues CMS-PKU-2A (H. annuus L.) and CMS-PRUN-29A (H. praecox ssp. Runyonii) recorded a highly significant GCA effect under both the environments for leaf area (Table 3). Among the testers lines, P69R was determined as a significant combiner under normal growth conditions while P100R was recorded significant under both the environments (Table 3). Among hybrids lines, twenty-three hybrids were determined to have a positive SCA effect under both growth regimes (Table S1). The top three common hybrids for SCA both of the environments were CMS-ARG-2A $\times$ RCR-8297, CMS-234A $\times$ P100R and CMS-XA $\times$ P69R (Table 4).

\subsubsection{Specific Leaf Weight (g)}

For specific leaf weight, CMS-PKU-2A was determined to have a highly significant GCA under both growth regimes (Table 3). Furthermore, the male parent line, P100R, was demonstrated to be a strong combiner for this trait under both growth regimes. In addition, 18 hybrid lines recorded highly positively significant SCA effects under both growth conditions (Table S1), and the top three common combinations for SCA were CMS-ARG-2A $\times$ RCR-8297, CMS-XA $\times$ P69R, and CMS-234A $\times$ P100R (Table 4).

\subsubsection{Leaf Area Index}

For leaf area index (LAI), the female parent CMS-PRUN-29A (0.89), from wild sources, and lines CMS-42A, CMS-234A and CMS-38A from the PET-1 source were recorded as significant general combiners (Table 3). Among male parents, P100R was observed to have a significant GCA effect (0.19 and 0.21) under both environments (Table 3). Out of the 60 hybrids, nineteen were recorded highly significant SCA for LAI under both growth regimes (Table S1), although the top three common combinations for SCA were CMS-ARG-2A $\times$ RCR-8297, CMS-234A $\times 100 R$ and CMS-38A $\times$ RCR-8297 (Table 4).

\subsubsection{Leaf Water Potential (MPa)}

For leaf water potential under the normal environment, CMS-ARG-3A was determined to be a significant combiner (Table 3). Under stress, lines CMS-E002-91A, CMS-PKU-2A and CMS-ARG-2A, CMS-234A, CMS-38A and NC-41B were determined to be better general combiners 
for leaf water potential (Table 3). A total of twenty-one hybrids were determined to have a significant positive SCA effects under normal growth conditions. Under the drought stress regime, twenty-seven were determined to possess good combining ability (Table S1). The best three cross combinations identified with high SCA effects for leaf water potential under both growth regimes were, CMS-PRUN-29A $\times$ RCR-8297, CMS-38A $\times$ RCR-8297, and 42B $\times$ P69R, respectively (Table 4).

\subsubsection{Relative Leaf Water Content (\%)}

Six of the nine CMS analogues, and both of the maintainer lines, initially determined to be significant general combiners for relative leaf water content, were also identified as good combiners under the normal environment (Table 3). Under the water stress growth regime, female lines CMA-XA, CMS-PKU-2A, CMS-ARG-2A and CMS-PHIR-27A from wild sources and CMS-NC-41B from the PET-1 source were observed as significant combiners (Table 3). A total of twenty-eight hybrids recorded significant positive SCA effects in the normal environment. Twenty-nine hybrids recorded significant positive SCA effects under the stress environment (Table S1). The three cross combinations, including linesCMS-234A $\times$ RCR-8297, CMS-E002-91A $\times$ P69R, and CMS-40A $\times$ P69R were identified with highly significant SCA effects for relative leaf water content under both growth regimes (Table 4).

\subsubsection{Photosynthetic Efficiency (Chlorophyll Meter Reading)}

For both growth regimes, the female parents CMS-234A was determined to have the highest GCA effect (5.56 and 4.68) (Table 3). Furthermore, the male parent RCR-8297 and P69R were recorded as a significant combiners $(0.93$ and $1.34 ; 1.67$ and 0.75$)$ under both growth regimes for photosynthetic efficiency (Table 3). Twenty-one cross combinations recorded significant positive SCA effects in the normal growth environment. Under water stress condition, seventeen cross combinations were identified to have high SCA values (Table S1). The cross combinations, CMS-PHIR-27A $\times$ P100R, CMS-38A $\times$ RCR-8297 and CMS-E002-91A $\times$ P100R were identified to have high SCA effects for photosynthetic efficiency when cultivated under both growth regimes (Table 4).

\subsubsection{Proline Content (mg/g of Dry Weight)}

The CMS analogues CMS-XA, CMS-E002-91A, CMS-ARG-6A and CMS-PRUN-29A were demonstrated to be strong combiners for proline content in the normal growth environment (Table 3 ). Whereas, under the stress conditions, CMS-XA, CMS-E002-91A, CMS-ARG-3A and CMS-PRUN-29A and CMS-234A were determined to be as a good general combiners (Table 3). The tester line, P69R, appeared to be the most significant general combiner for proline content under both growth regimes. The hybrid lines, 42B $\times$ RCR-8297, CMS-XA $\times$ P69R and CMS-PRUN-29A $\times$ P124R were determined to have the most highly significant positive SCA effects for both growth conditions assessed (Table 4 ).

\subsubsection{Seed Yield (g/Plant)}

For the seed yield under normal growth conditions, the CMS analogues CMS-E002-91A (1.75), CMS-ARG-3A (5.17), CMS-ARG-6A (7.21) and CMS-40A (3.84) from wild sources, and linesCMS-42A (3.18) and CMS-234A (3.39) from the PET-1 background, were identified as significant performers for the GCA effects (Table 3). Whereas, under water-limited conditions, the CMS analogues CMS-XA (6.60), CMS-E002-91A (1.82), CMS-ARG-3A (4.80), CMS-ARG-6A (3.78), CMS-PRUN-29A (8.98) and CMS-234A (3.44) had highly significant GCA effects for seed yield (Table 3). The CMS analogues CMS-E002-91A, CMS-ARG-2A, CMS-ARG-3A and CMS-234A were determined to have SCA under both assessed growth regimes. Twenty hybrids recorded highly significant positive SCA effects under normal growth conditions while twenty-six hybrids reported positive SCA effects under the water stress growth regime (Table S1). 


\subsubsection{Biological Yield (g/Plant)}

Lines CMS-DV-10A and CMS-XA were good combiners for biological yield from the wild sources under a normal environment (Table 3). Whereas, for the water stress environment, the female lines CMS-XA, CMS-ARG-6A and CMS-PRUN-29A were identified as significant combiners while plant line CMS-E002-91A was also identified as a significant combiner for this trait. CMS-234A (111.49 and 93.32) and CMS-PRUN-29A (48.11 and 31.44) were also identified as significant for biological yield per plant under both normal and stress environments (Table 3). The tester line, P69R, returned to best performance with respect to biological yield for both growth regimes (23.20 and 60.37). Furthermore, the three best behaving for the hybrid lines for SCA for biological yield were lines, were CMS-38A $\times$ RCR-8297, CMS-XA $\times$ P124R and CMS-ARG-6A $\times$ P124R (Table 4).

\subsubsection{Harvest Index (\%)}

All CMS analogues from wild sources were identified to be very good combiners, except CMS-ARG-6A. Interestingly, and stemming from PET-1 source, none of the female lines had significant GCA for harvest index when cultivated in a water stressed environment (Table 3). The tester line, RCR-8297 appeared to be a good general combiner for harvest index with significant and positive GCA effects (2.54 and 2.88) under both growth regimes (Table 3). Twenty-four hybrids for the normal growth environment and twenty hybrids for water stress growth environment, were identified as significant positive SCA effects (Table S1). Hybrid lines, CMS-PHIR-27A $\times$ RCR-8297, 42B $\times$ P100R and CMS-ARG-3A $\times$ P124R were identified to have most significant SCA effects for either growth regime (Table 4).

\subsubsection{Oil Content (\%)}

CMS analogues CMS-XA (1.40), CMS-ARG-2A (1.29), CMS-PRUN-29A (0.75), CMS-42A (0.66) and CMS-234A (0.49) were identified as most significant general combiners under the normal growth conditions with respect to the oil content (Table 3). Whereas, for water stress growth environment, all CMS analogues for lines, CMS-ARG-6A and CMS-PHIR-27A were identified as significant combiners for oil content (Table 3). The male parent lines, RCR-8297 and P69R were recorded as highly significant general combiners for the stress environment, while line P100R was identified as a significant general combiner for the normal growth environment (Table 3). In addition, twenty-two hybrids under the normal environment and twenty-eight hybrids under the stress environment were identified to have a significant positive SCA effects on oil content (Table S1). 
Table 3. The estimates for the general combining ability (GCA) of the parental genotypes (19) under normal and under water stress for the 12 plant descriptors.

\begin{tabular}{|c|c|c|c|c|c|c|c|c|c|c|c|c|}
\hline Parents & $\begin{array}{c}\text { Number of } \\
\text { Leaves }\end{array}$ & $\begin{array}{l}\text { Leaf } \\
\text { Area }\end{array}$ & $\begin{array}{c}\text { Specific Leaf } \\
\text { Weight }\end{array}$ & $\begin{array}{l}\text { Leaf Area } \\
\text { Index }\end{array}$ & $\begin{array}{c}\text { Leaf Water } \\
\text { Potential }\end{array}$ & $\begin{array}{c}\text { Relative Leaf } \\
\text { Water Content }\end{array}$ & $\begin{array}{c}\text { Photosynthetic } \\
\text { Efficiency }\end{array}$ & $\begin{array}{l}\text { Proline } \\
\text { Content }\end{array}$ & $\begin{array}{c}\text { Biological } \\
\text { Yield }\end{array}$ & $\begin{array}{c}\text { Harvest } \\
\text { Index }\end{array}$ & $\begin{array}{l}\text { Seed } \\
\text { Yield }\end{array}$ & $\begin{array}{c}\text { Oil } \\
\text { Content }\end{array}$ \\
\hline \multicolumn{13}{|c|}{ GCA Under Non-stressed Environment } \\
\hline CMS-XA & -4.43 & -0.11 & -0.06 & -0.61 & 0.001 & -0.75 & $0.79 * *$ & $0.10 * *$ & $8.76^{*}$ & $0.65 *$ & -1.3 & 1.40 ** \\
\hline CMS-E002-91A & -2.35 & -0.12 & -0.19 & -0.67 & $0.07^{* *}$ & $5.09 * *$ & -0.46 & $0.07^{* *}$ & $26.47^{* *}$ & -1.3 & $1.75^{* *}$ & -1.45 \\
\hline CMS-PKU-2A & -1.47 & $0.13^{* *}$ & $0.37 * *$ & $0.73 * *$ & -0.1 & $2.44^{* *}$ & -1.3 & -0.07 & -23.55 & 0.14 & 0.16 & -0.21 \\
\hline CMS-ARG-2A & -3.45 & -0.02 & $0.09 * *$ & -0.11 & -0.11 & $2.06 * *$ & -2.01 & $0.02^{*}$ & -40.94 & -1.42 & -2.90 & $1.29 * *$ \\
\hline CMS-ARG-3A & -3.94 & -0.12 & -0.03 & -0.64 & $0.25 * *$ & $6.94 * *$ & -5.98 & -0.03 & $52.69 * *$ & $1.11^{* *}$ & $5.17^{* *}$ & -0.24 \\
\hline CMS-ARG-6A & $2.33 * *$ & -0.03 & -0.12 & -0.31 & -0.08 & $1.50 * *$ & $0.77^{* *}$ & $0.03 * *$ & -30.93 & $2.65^{* *}$ & $7.21 * *$ & -0.37 \\
\hline CMS-DV-10A & 0.12 & -0.03 & -0.04 & -0.12 & -0.04 & -3.09 & -3.09 & -0.08 & $8.97 *$ & -0.38 & 0.21 & -0.75 \\
\hline CMS-PHIR-27A & -0.34 & -0.13 & -0.28 & -0.7 & $0.21 * *$ & $5.03 * *$ & $1.62 * *$ & -0.02 & -5.51 & $1.91^{* *}$ & 1.00 & -0.81 \\
\hline CMS-PRUN-29A & -0.41 & $0.16^{* *}$ & $0.32 * *$ & $0.89 * *$ & -0.22 & -5.61 & 3.57 ** & $0.08^{* *}$ & $48.11 * *$ & 0.33 & 1.07 & $1.94^{* *}$ \\
\hline CMS-40A & $2.82 * *$ & -0.08 & -0.24 & -0.4 & $0.04 *$ & -0.87 & $0.64 * *$ & -0.02 & -21.66 & $1.00^{* *}$ & $3.84 * *$ & -0.25 \\
\hline CMS-42A & $1.86^{* *}$ & $0.14^{* *}$ & $0.18 * *$ & $0.82 * *$ & $0.14 * *$ & -8.02 & -2.12 & -0.06 & -9.99 & -0.52 & $3.18^{* *}$ & $0.66^{* *}$ \\
\hline CMS-234A & $1.58 * *$ & $0.16^{* *}$ & -0.01 & $0.88 * *$ & $0.20 * *$ & -8.97 & $5.56^{* *}$ & 0.01 & $111.49 * *$ & -2.2 & $3.39 * *$ & $0.49^{* *}$ \\
\hline CMS-38A & $1.29^{* *}$ & $0.09 * *$ & $0.07 * *$ & $0.43^{* *}$ & -0.18 & -7.76 & $1.25 * *$ & -0.01 & -81.18 & 0.05 & -7.13 & -0.65 \\
\hline NC-41B (C) & -1.47 & -0.04 & -0.01 & -0.22 & -0.1 & $5.01 * *$ & $1.35^{* *}$ & -0.02 & 5.95 & $1.04^{* *}$ & -5.24 & -1.85 \\
\hline $42 \mathrm{~B}$ & $0.86^{* *}$ & 0.001 & -0.06 & 0.01 & -0.07 & $6.98 * *$ & -0.6 & $0.02 *$ & -48.68 & -3.05 & -10.4 & $0.81 * *$ \\
\hline RCR-8297 & $0.26^{* *}$ & -0.02 & -0.03 & -0.06 & $0.05^{* *}$ & -0.19 & $0.93 * *$ & 0.001 & -18.32 & $2.54^{* *}$ & $3.15^{* *}$ & -0.27 \\
\hline P69R & $1.09 * *$ & $0.03^{* *}$ & 0.01 & $0.16^{* *}$ & -0.14 & $2.21^{* *}$ & $1.67^{* *}$ & $0.04 * *$ & 23.20 ** & -0.85 & -3.5 & -0.14 \\
\hline P124R & -0.29 & -0.05 & -0.09 & -0.28 & $0.02 *$ & -2.33 & -1.95 & -0.02 & -27.59 & 0.17 & -2.1 & -0.28 \\
\hline P100R & -1.06 & $0.04^{* *}$ & $0.11^{* *}$ & $0.19^{* *}$ & $0.07^{* *}$ & $0.30 * *$ & -0.64 & -0.02 & 22.71 ** & -1.86 & $2.44^{* *}$ & $0.68^{* *}$ \\
\hline \multicolumn{13}{|c|}{ GCA Under Stressed Environment } \\
\hline CMS-XA & -1.36 & -0.08 & -0.12 & -0.37 & -0.1 & $6.28 * *$ & -0.75 & $0.32 * *$ & $15.09 * *$ & $2.34^{* *}$ & $6.60 * *$ & $0.22 * *$ \\
\hline CMS-E002-91A & 0.19 & $0.04 * *$ & $0.08 * *$ & $0.32 * *$ & $0.15^{* *}$ & -7.82 & -0.07 & $0.24 * *$ & $-10.51 *$ & $1.93 * *$ & $1.82 * *$ & $0.36^{* *}$ \\
\hline CMS-PKU-2A & -0.98 & $0.10^{* *}$ & $0.27 * *$ & $0.64 * *$ & $0.12 * *$ & $4.08 * *$ & -1.42 & -0.22 & -49.58 & $6.01 * *$ & -0.8 & $1.86^{* *}$ \\
\hline CMS-ARG-2A & -2.78 & -0.07 & -0.02 & -0.29 & $0.41 * *$ & $5.18 * *$ & 0.19 & $0.08 * *$ & -57.42 & $1.54^{* *}$ & -3.82 & $1.58^{* *}$ \\
\hline CMS-ARG-3A & -1.79 & -0.17 & -0.31 & -0.85 & -0.14 & -2.72 & -1.79 & -0.06 & -13.07 & $1.59 * *$ & $4.80 * *$ & $3.23 * *$ \\
\hline CMS-ARG-6A & $1.99 * *$ & $0.03 * *$ & 0.001 & -0.05 & -0.22 & -4.9 & $2.18 * *$ & -0.09 & $14.80 * *$ & 0.41 & $3.78^{* *}$ & -0.45 \\
\hline CMS-DV-10A & -3.00 & -0.06 & 0.03 & -0.25 & -0.26 & -7.56 & -2.33 & -0.22 & -58.69 & $3.27^{* *}$ & -0.04 & $0.68^{* *}$ \\
\hline CMS-PHIR-27A & -2.94 & -0.13 & -0.2 & -0.63 & -0.22 & $2.62 * *$ & -2.27 & -0.04 & -45.97 & $1.88^{* *}$ & -0.79 & -1.22 \\
\hline CMS-PRUN-29A & -2.12 & $0.06^{* *}$ & $0.22 * *$ & $0.41^{* *}$ & -0.03 & -0.61 & -0.09 & $0.28 * *$ & $31.44^{* *}$ & $3.43^{* *}$ & $8.98 * *$ & $1.15^{* *}$ \\
\hline CMS-40A & $3.92 * *$ & -0.02 & -0.11 & -0.19 & -0.16 & -4.99 & $0.80^{* *}$ & -0.19 & $74.96^{* *}$ & -2.94 & 0.69 & -0.52 \\
\hline CMS-42A & $1.63^{* *}$ & $0.18^{* *}$ & $0.29^{* *}$ & $1.05 * *$ & -0.18 & $2.42 * *$ & -0.82 & -0.18 & -11.28 & -1.72 & 0.53 & -0.58 \\
\hline CMS-234A & $1.53 * *$ & $0.09 * *$ & -0.1 & $0.59^{* *}$ & $0.20 * *$ & -2.04 & $4.68^{* *}$ & $0.03 * *$ & $93.32 * *$ & -2.84 & $3.44^{* *}$ & $0.27^{* *}$ \\
\hline CMS-38A & $1.42 * *$ & $0.02^{*}$ & -0.13 & -0.23 & $0.22 * *$ & -2.17 & $0.96 * *$ & $0.02 *$ & -61.22 & -1.59 & -7.12 & -0.01 \\
\hline NC-41B (C) & -4.81 & -0.06 & $0.15 * *$ & -0.27 & $0.21 * *$ & $11.77^{* *}$ & $1.50 * *$ & -0.03 & 7.63 & -7.67 & -15.49 & -4.71 \\
\hline $42 \mathrm{~B}$ & $3.10 * *$ & $0.08 * *$ & -0.07 & $0.11 * *$ & 0.01 & 0.47 & -0.78 & $0.06 * *$ & $70.51^{* *}$ & -5.63 & -2.59 & -1.85 \\
\hline RCR-8297 & -0.27 & 0.001 & $0.04^{* *}$ & $0.08 * *$ & 0.01 & $1.58 * *$ & $1.34 * *$ & $0.03 * *$ & -28.1 & $2.88^{* *}$ & $1.70 * *$ & $0.34^{* *}$ \\
\hline P69R & $0.96^{* *}$ & -0.01 & -0.06 & -0.03 & -0.05 & -2.96 & $0.75^{* *}$ & $0.07 * *$ & $60.37^{* *}$ & -3.15 & -1.05 & 0.32 ** \\
\hline P124R & -0.13 & -0.04 & -0.08 & $-0.26^{* *}$ & $0.16^{* *}$ & $0.50 * *$ & -1.46 & -0.03 & -21.67 & $1.38^{* *}$ & -1.06 & -0.35 \\
\hline P100R & -0.56 & $0.05^{* *}$ & $0.10 * *$ & $0.21^{* *}$ & -0.11 & $0.88 * *$ & -0.64 & -0.07 & -10.6 & -1.11 & 0.41 & -0.31 \\
\hline
\end{tabular}

**, * indicate significant at $p<0.01$, or $p<0.05$, respectively. 
Table 4. Common three significant cross combinations with high specific combining ability (SCA).

\begin{tabular}{|c|c|c|c|}
\hline Traits & Crosses & $\mathbf{N}$ & S \\
\hline \multirow[t]{3}{*}{ Number of leaves } & CMS-38A $\times$ RCR-8297 & $4.65^{* *}$ & $1.79^{* *}$ \\
\hline & CMS-ARG-6A $\times$ P124R & $3.08 * *$ & $2.65^{* *}$ \\
\hline & $\mathrm{CMS}-40 \mathrm{~A} \times \mathrm{P} 124 \mathrm{R}$ & $2.22 * *$ & $1.01^{* *}$ \\
\hline \multirow[t]{3}{*}{ Leaf area } & CMS-ARG-2A $\times$ RCR-8297 & $0.42 * *$ & $0.38^{* *}$ \\
\hline & CMS-234A $\times$ P100R & $0.34 * *$ & $0.31^{* *}$ \\
\hline & CMS-XA $\times$ P69R & $0.23 * *$ & $0.03^{* *}$ \\
\hline \multirow[t]{3}{*}{ Specific leaf weight } & CMS-ARG-2A $\times$ RCR-8297 & $0.88^{* *}$ & $0.82 * *$ \\
\hline & CMS-XA $\times$ P69R & $0.67 * *$ & $0.13^{* *}$ \\
\hline & CMS-234A $\times$ P100R & $0.44^{* *}$ & $0.45^{* *}$ \\
\hline \multirow[t]{3}{*}{ Leaf area index } & CMS-ARG-2A $\times$ RCR-8297 & $2.25 * *$ & $2.01 * *$ \\
\hline & CMS-234A $\times$ P100R & $1.90 * *$ & $1.79^{* *}$ \\
\hline & CMS-38A $\times$ RCR-8297 & $1.09 * *$ & $1.13^{* *}$ \\
\hline \multirow[t]{3}{*}{ Leaf water potential } & CMS-PRUN-29A $\times$ RCR-8297 & $0.45^{* *}$ & $0.13^{* *}$ \\
\hline & CMS-38A $\times$ RCR-8297 & $0.40 * *$ & $0.28^{* *}$ \\
\hline & $42 B \times P 69 R$ & $0.33^{* *}$ & $0.33^{* *}$ \\
\hline \multirow[t]{3}{*}{ Relative leaf water content } & CMS-234A × RCR-8297 & $5.94 * *$ & $17.21^{* *}$ \\
\hline & CMS-E002-91A $\times$ P69R & $5.77 * *$ & $7.54^{* *}$ \\
\hline & CMS-40A $\times$ P69R & $5.70 * *$ & $7.52 * *$ \\
\hline \multirow[t]{3}{*}{ Photosynthetic efficiency } & CMS-PHIR-27A $\times$ P100R & $4.21 * *$ & $1.18^{* *}$ \\
\hline & CMS-38A $\times$ RCR-8297 & $3.95 * *$ & $7.14^{* *}$ \\
\hline & CMS-E002-91A $\times$ P100R & $1.97 * *$ & $2.85^{* *}$ \\
\hline \multirow[t]{3}{*}{ Proline content } & 42B $\times$ RCR-8297 & $0.20 * *$ & $0.62 * *$ \\
\hline & CMS-XA $\times$ P69R & $0.18 * *$ & $0.60 * *$ \\
\hline & CMS-PRUN-29A × P124R & $0.14^{* *}$ & $0.38^{* *}$ \\
\hline \multirow[t]{3}{*}{ Biological yield } & CMS-38A $\times$ RCR-8297 & $98.05^{* *}$ & $58.42 * *$ \\
\hline & CMS-XA $\times$ P124R & $84.12^{* *}$ & $58.67^{* *}$ \\
\hline & CMS-ARG-6A $\times$ P124R & $67.40^{* *}$ & $184.79^{* *}$ \\
\hline \multirow[t]{3}{*}{ Harvest index } & CMS-PHIR-27A × RCR-8297 & $9.10 * *$ & $2.47^{* *}$ \\
\hline & $42 \mathrm{~B} \times \mathrm{P} 100 \mathrm{R}$ & $5.39 * *$ & $2.83^{* *}$ \\
\hline & CMS-ARG-3A $\times$ P124R & $5.18 * *$ & $4.42 * *$ \\
\hline \multirow[t]{3}{*}{ Seed yield } & CMS-ARG-2A $\times$ P100R & $9.97 * *$ & $10.70 * *$ \\
\hline & CMS-PKU-2A $\times$ P124R & $8.31 * *$ & $7.46^{* *}$ \\
\hline & $42 B \times P 69 R$ & $8.14^{* *}$ & $11.60^{* *}$ \\
\hline \multirow[t]{3}{*}{ Oil content } & CMS-E002-91A $\times$ P124R & $2.11^{* *}$ & $1.62 * *$ \\
\hline & NC-41B (C) × RCR-8297 & $2.08^{* *}$ & $3.32 * *$ \\
\hline & CMS-PRUN-29A $\times$ P100R & $2.03 * *$ & $1.77^{* *}$ \\
\hline
\end{tabular}

\subsection{Correlations}

For sunflower lines cultivated under normal growth regime, 16 correlation coefficients were found to be significant $(p<0.05)$ (Figure 2). Among these, five were negative correlations and three were demonstrated to be absolute correlations. Harvest index negatively correlated with biological yield, specific leaf weight, and leaf area index (Figure 2). While absolute correlations were established for between leaf area and leaf area index, and with specific leaf weight to leaf area and leaf area index (0.92) (Figure 2). Furthermore, and for water stress growth environment, a total of 14 correlation coefficients were determined to be significant $(p<0.05)$ (Figure 3$)$. Thirteen of these were positive correlations 
and one was a negative correlation namely the correlation of harvest index to biological yield ( -0.59$)$ (Figure 3). In addition, specific leaf weight was absolutely correlated with leaf area (0.90) and leaf area index (0.92) (Figure 3), and seed yield was determined to be correlated with the oil content (0.49), number of leaves (0.44), and biological yield (0.43) (Figure 3). The number of leaves per plant and plant's biological yield (0.46) was found correlated. Also for the water stress growth regime, the leaf water potential was correlated with leaf area, leaf area index and specific leaf weight in water-limited conditions (Figure 3).

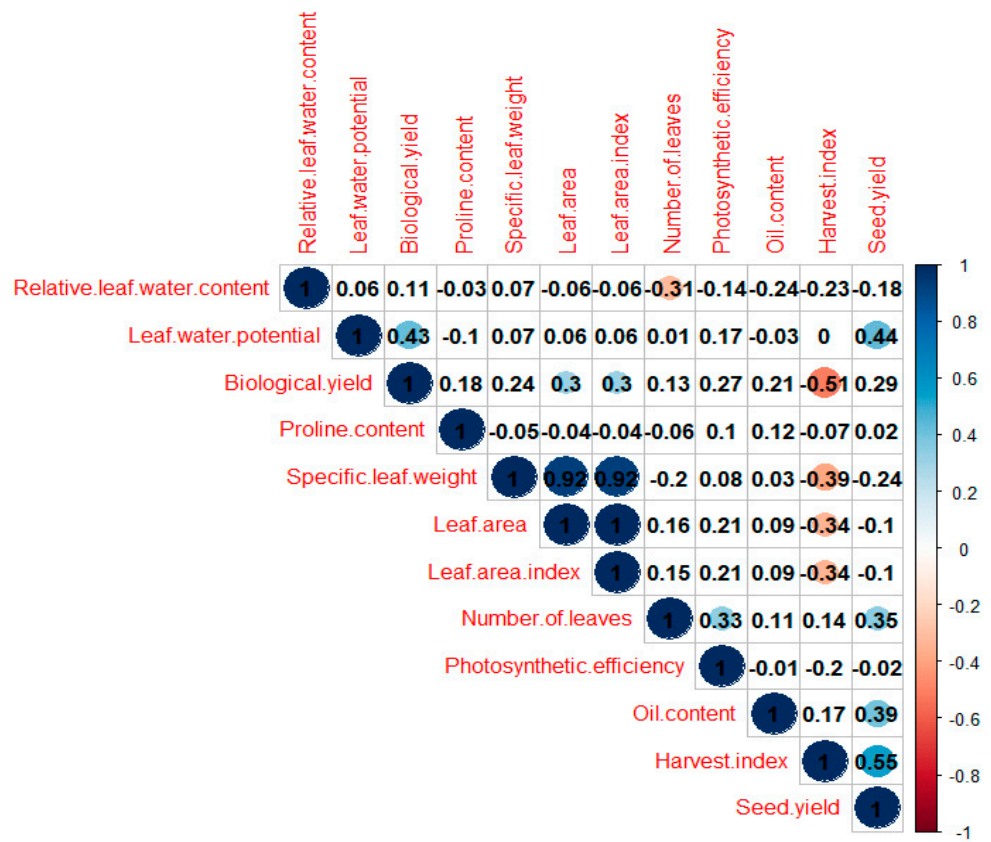

Figure 2. Pearson's correlation coefficients for the assessed sunflower lines cultivated under a normal growth regime with significant values $p<0.05$ highlighted.

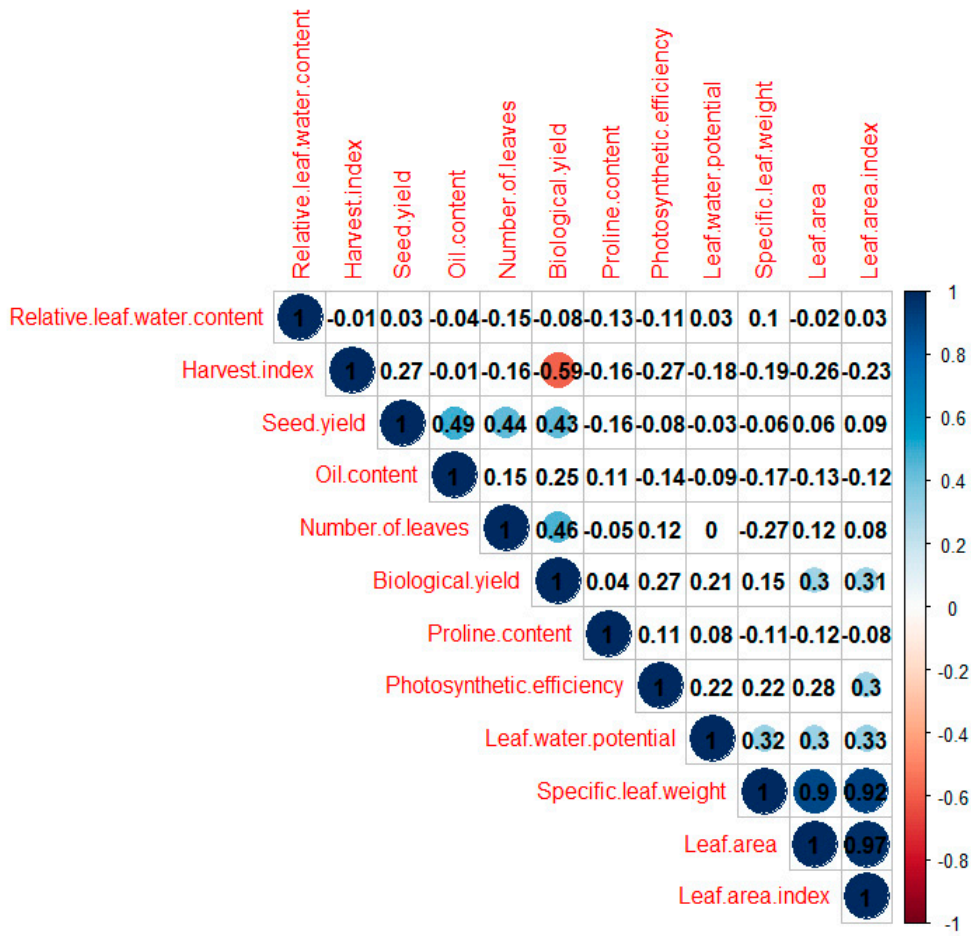

Figure 3. Pearson's correlation coefficients for the assessed sunflower lines cultivated under the water-stressed growth regime with significant values od $p<0.05$ highlighted. 


\section{Discussion}

Wild relatives of cultivated cropping species are widely recognized as important sources of valuable genes for the breeding objective of drought tolerance [34-36]. In major crops (cereals) some of the central genes for drought tolerance have been identified, and furthermore, several of these genes have been integrated into the genome of cultivated varieties $[37,38]$. For sunflower, however, in sunflower, only $H$. argophyllus has been extensively studied for drought tolerance [23,39]. Frequently when wild relatives are used in breeding programs, the resulting progeny display reduced total yield, and these yields are also of a lower quality [40]. However, when the progeny resulting from these breeding experiments are cultivated under drought stress conditions, frequently the opposite is observed, that is; the progeny display superior growth performance [24]. In the case of sunflower, the problem of cytoplasm homogeny can lead to potential problems in the future [41]. Also, the balanced effect of cytoplasm and nuclear genome requires extensive additional study before commercialization of any newly generated sunflower varieties as evidence exists that such nucleus-cytoplasm interaction can results in reduced yields in these lines [42].

Here we assessed the phenotypic and physiological characteristics of the 13 CMS lines, 2 maintainer lines, 4 restorer lines, along with 60 F1 hybrid lines derived from six wild relatives of cultivated sunflower. This study is among the largest studies carried out in sunflower to study cytoplasmic effects along with drought tolerance. Mostly, we have identified cross combinations with wild species that are more significant under water-limited growth conditions. For drought tolerance, we have specifically identified that proline content was three times more abundant in the leaves of stressed plants, compared with those samples from non-stressed plants. Taken together, the extensive analysis performed here, are highly supportive of previous demonstrations in sunflower and other oilseed cropping species [24,43].

The overall significant differences in mean values showed a substantial amount of variation for all assessed traits. It was readily apparent that different cytoplasmic sources influenced traits under both conditions. Earlier studies reported the effect of cytoplasm sources on different traits and it was concluded that the cytoplasmic genome affects qualitative and quantitative traits [44-46]. SCA effects are more important for cross-pollinated plants, whereas CGA effects are more important for self-pollinated plants [47]. Being a cross-pollinating species, sunflower showed significantly higher SCA values than corresponding GCA values for most of the 12 descriptors. Moreover, the importance of combining ability in a selection of parents for hybridization has been well emphasized by previous sunflower studies [48-50].

The non-additive gene effects have been previously identified governing the inheritance of important traits such as leaf area, specific leaf weight, leaf area index, leaf water potential, relative leaf water content, photosynthetic efficiency, proline content, seed yield, harvest index and oil content under normal and water limited growth regime [23,51,52]. Specifically, dies an early study, reported non-additive gene action for seed yield and oil content while additive gene action for oil content [53]. In contrast, a separate study reported additive gene action for the inheritance of seed yield, oil content etc. [54]. Overall, the female parents (lines) had a larger influence in the expression of traits than the male parent lines, a finding that further confirms the role of cytoplasmic and nuclear interactions in the expression of these traits. This also shows the importance of plant material diversity used for such studies [55]. Similarly, significant GCA effect for seed yield was reported in previous studies in that parent which were good general combiners for economic traits might be extensively used in hybridization programs to identify suitable additional parental lines for hybridization and developing potential hybrids for seed yield [56,57]. The female lines CMS-234A from cultivated source and CMS-XA, ARG-2A and PRUN-29A from the wild relative source were identified as good combiners for oil content. Among tester lines assessed, line RCR-8297 for seed yield under both environments and lines RCR-8297 and P69R for oil content in the stress growth regime with high positive GCA estimates are desirable parents to be used for developing sunflower hybrids with improved oil content $[54,58,59]$. 
The hybrids CMS-XA $\times$ P100R, CMS-ARG-2A $\times$ P100R, and 42B $\times$ RCR-8297 were considered as the best specific combiners for seed yield lines, CMS-E002-91A $\times$ P124R, CMS-E002-91A $\times$ P100R, and CMS-40A $\times$ P124R for oil content. Higher positive SCA effects indicated that these desirable traits are influenced by dominance and/or overdominance gene action. In concordance with the finding reported here, higher positive SCA for head diameter; for 1000-achene weight; and for seed yield and yield-related traits and for oil content have been reported previously [60-62] The heterotic performance of hybrid combinations depends upon the combining abilities of their parents [61]. The superior hybrids were obtained by crossing CMS females and restorer males with high GCA and SCA effects [56]. The overall variation among CMS lines for the assessed traits were greater than the restorer lines indicating some degrees of maternal effect on traits, particularly for seed and oil yield [63]. The seed yield was found correlated under both the environments to harvest index, number of leaves and oil content. While proline content was not correlated with any of the descriptors, under biotic stress, the yield was independent of other traits [62].

\section{Materials and Methods}

\subsection{Experimental Layout and Material}

The open experimental fields were settled at the research farm of Punjab Agricultural University, Ludhiana, India (coordinates at $30^{\circ} 54^{\prime} 6^{\prime \prime} \mathrm{N} 75^{\circ} 48^{\prime} 27^{\prime \prime}$ E). The experimental material comprised 19 genotypes of sunflower in the form of different species (Table 5). Among them, 9 were alloplasmic CMS (A) lines, 4 euplasmic CMS lines (A), 2 maintainer lines (B), and 4 restorer lines (R) (Table 5). Both, A lines (13) and B lines (2) were crossed with the R lines (4) to produce sixty one-way F1 hybrids (Table 5). The hybrids were produced as the nine alloplasmic lines and euplasmic CMS lines from petiolaris source were crossed with restorers to synthesize a set of $52 \mathrm{~A} \times \mathrm{R}$ crosses (Table 5). Subsequently, both maintainer lines were made sterile using gibberellic acid $\left(\mathrm{GA}_{3}\right)(100 \mathrm{ppm})$ at the star bud initiation stage for three consecutive days [64,65]. Thereafter, these maintainer lines were also crossed with the restorer lines to synthesize a set of eight $B \times R$ crosses (Table 1 ). The study was conducted over the period of two years i.e., 1st year from February 2011 and 2nd year in the February 2012. In the first year of the experiment, a total of $52 \mathrm{~A} \times \mathrm{R}$ crosses and $8 \mathrm{~B} \times \mathrm{R}$ crosses along with parental lines were planted in February 2011 via a randomized complete block design (RCBD) with three replications. In the field, each parental genotype (19) and cross combination (60) was represented by a plot of two rows $\left(3 \mathrm{~m}^{2}\right.$ each) with an inter- and intra-row spacing maintained at $60 \mathrm{~cm}$ and $30 \mathrm{~cm}$, respectively. There were 20 plants (10 in each plot) of every parent and their hybrids in each replication. Similarly, the nearby field was chosen for the drought screening trial, the same set of experiment was repeated with a different water regime by withholding irrigation during anthesis and soft dough stages of crop growth [66]. The same experiment was repeated in the February 2012 for the second-year evaluation trial. 
Table 5. List of sunflower accessions along with their source (species) and hybrids used for the characterization.

\begin{tabular}{|c|c|c|c|c|c|}
\hline \multirow[t]{2}{*}{ A/B/R Lines Accessions } & \multirow[t]{2}{*}{ Species } & \multicolumn{4}{|c|}{ Hybrids } \\
\hline & & RCR-8297 & P69R & P124R & P100R \\
\hline \multicolumn{6}{|c|}{ A Lines (Alloplasmic) } \\
\hline CMS-XA & Unknown & CMS-XA $\times$ RCR-8297 & CMS-XA $\times$ P69R & CMS-XA $\times$ P124R & CMS-XA $\times$ P100R \\
\hline CMS-E002-91A & H. аппиия $\mathrm{L}$. & CMS-E002-91A × RCR-8297 & CMS-E002-91A × P69R & CMS-E002-91A × P124R & CMS-E002-91A $\times$ P100R \\
\hline CMS-PKU-2A & H. апnиนs & CMS-PKU-2A × RCR-8297 & CMS-PKU-2A × P69R & CMS-PKU-2A × P124R & CMS-PKU-2A $\times$ P100R \\
\hline CMS-ARG-2A & H. argophyllus Torr. \& A.Gray & ARG-2A $\times$ RCR-8297 & CMS-ARG-2A $\times$ P69R & CMS-ARG-2A $\times$ P124R & CMS-ARG-2A $\times$ P100R \\
\hline CMS-ARG-3A & H. argophyllus & CMS-ARG-3A × RCR-8297 & CMS-ARG-3A $\times$ P69R & CMS-ARG-3A $\times$ P124R & CMS-ARG-3A $\times$ P100R \\
\hline CMS-ARG-6A & H. argophyllus & CMS-ARG-6A × RCR-8297 & CMS-ARG-6A $\times$ P69R & CMS-ARG-6A $\times$ P124R & CMS-ARG-6A $\times$ P100R \\
\hline CMS-DV-10A & H. debilis ssp. Vestitus Nutt. & CMS-DV-10A × RCR-8297 & CMS-DV-10A $\times$ P69R & CMS-DV-10A $\times$ P124R & CMS-DV-10A $\times$ P100R \\
\hline CMS-PHIR-27A & H. praecox ssp. Hirtus Engelm. \& A.Gray & CMS-PHIR-27A $\times$ RCR-8297 & CMS-PHIR-27A $\times$ P69R & CMS-PHIR-27A × P124R & CMS-PHIR-27A $\times$ P100R \\
\hline CMS-PRUN-29A & H. praecox ssp. Runyonii Engelm. \& A.Gray & CMS-PRUN-29A $\times$ RCR-8297 & CMS-PRUN-29A $\times$ P69R & CMS-PRUN-29A $\times$ P124R & CMS-PRUN-29A $\times$ P100R \\
\hline \multicolumn{6}{|c|}{ A Lines (Euplasmic) } \\
\hline CMS-40A & H. petiolaris (conventional) Siebold \& Zucc. & CMS-40A $\times$ RCR-8297 & CMS-40A $\times$ P69R & CMS-40A $\times$ P124R & CMS-40A $\times$ P100R \\
\hline CMS-42A & H. petiolaris (conventional) & CMS-42A × RCR-8297 & CMS-42A $\times$ P69R & CMS-42A $\times$ P124R & CMS-42A $\times$ P100R \\
\hline CMS-234A & H. petiolaris (conventional) & CMS-234A $\times$ RCR-8297 & CMS-234A $\times$ P69R & $\mathrm{CMS}-234 \mathrm{~A} \times \mathrm{P} 124 \mathrm{R}$ & CMS-234A $\times$ P100R \\
\hline CMS-38A & H. petiolaris (conventional) & CMS-38A $\times$ RCR-8297 & CMS-38A $\times$ P69R & CMS-38A $\times$ P124R & CMS-38A $\times$ P100R \\
\hline \multicolumn{6}{|c|}{ B Lines (Maintainer) } \\
\hline NC-41B & H. petiolaris (conventional) & NC-41B $\times$ RCR-8297 & $\mathrm{NC}-41 \mathrm{~B} \times \mathrm{P} 69 \mathrm{R}$ & NC-41B $\times$ P124R & NC-41B $\times$ P100R \\
\hline $42 B$ & H. petiolaris (conventional) & 42B $\times$ RCR-8297 & $42 \mathrm{~B} \times \mathrm{P} 69 \mathrm{R}$ & $42 \mathrm{~B} \times \mathrm{P} 124 \mathrm{R}$ & $42 \mathrm{~B} \times \mathrm{P} 100 \mathrm{R}$ \\
\hline \multicolumn{6}{|c|}{ R Lines (Restorer) } \\
\hline RCR-8297 & H. апnиus & & & & \\
\hline $\mathrm{P} 69 \mathrm{R}$ & Н. аппиия & & & & \\
\hline P124R & H. апnиนs & & & & \\
\hline P100R & H. annuиs & & & & \\
\hline
\end{tabular}




\subsection{Weather Parameters and Soil Properties}

The meteorological data (weekly intervals) during the entire crop season of 2011 (February 2011 to June 2011) and 2012 (February 2012 to June 2012) is represented in Figure 4. The air temperature ranged from $4.2^{\circ} \mathrm{C}$ to $43.7^{\circ} \mathrm{C}$ (Figure 4 ).

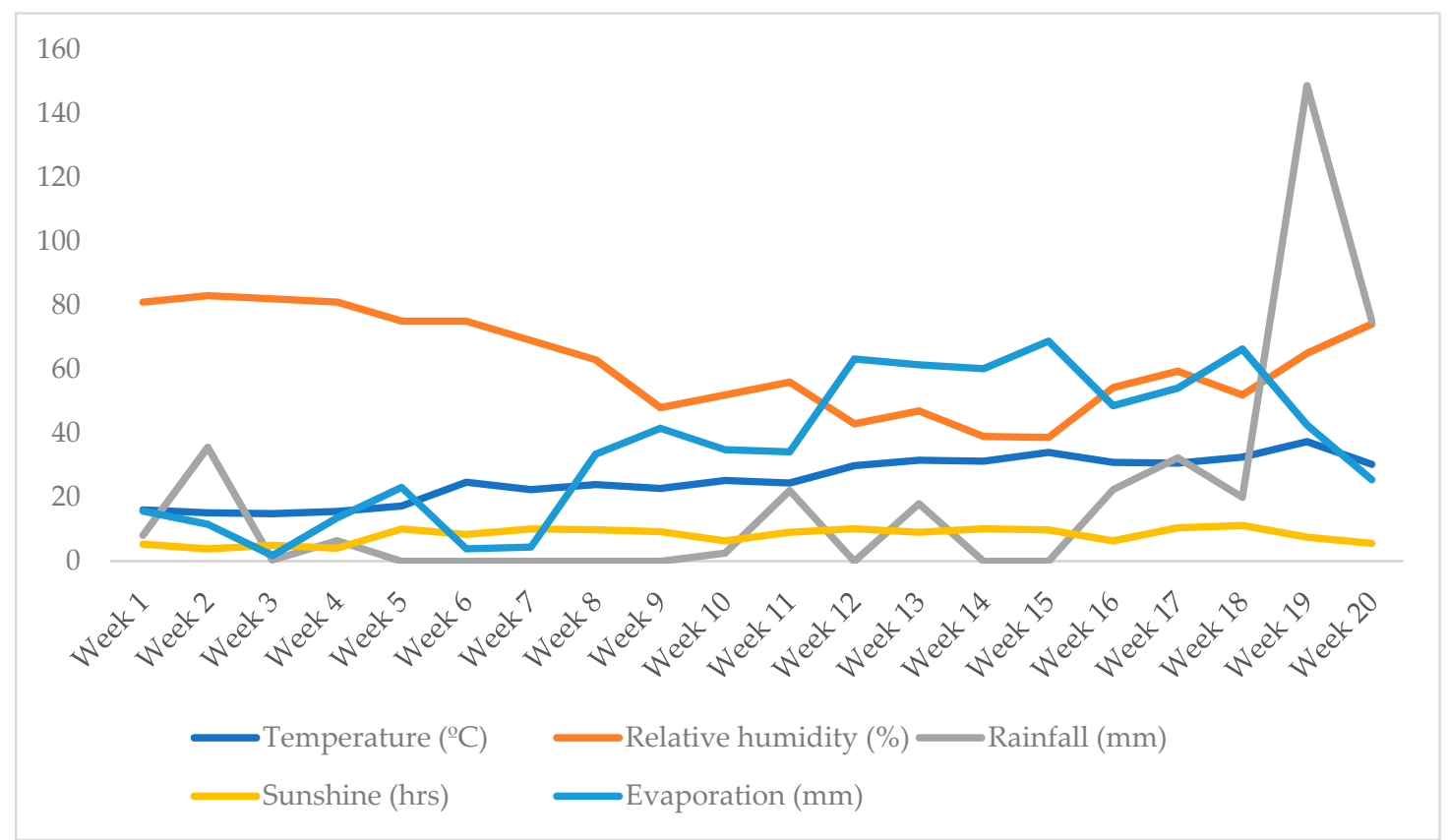

(A)

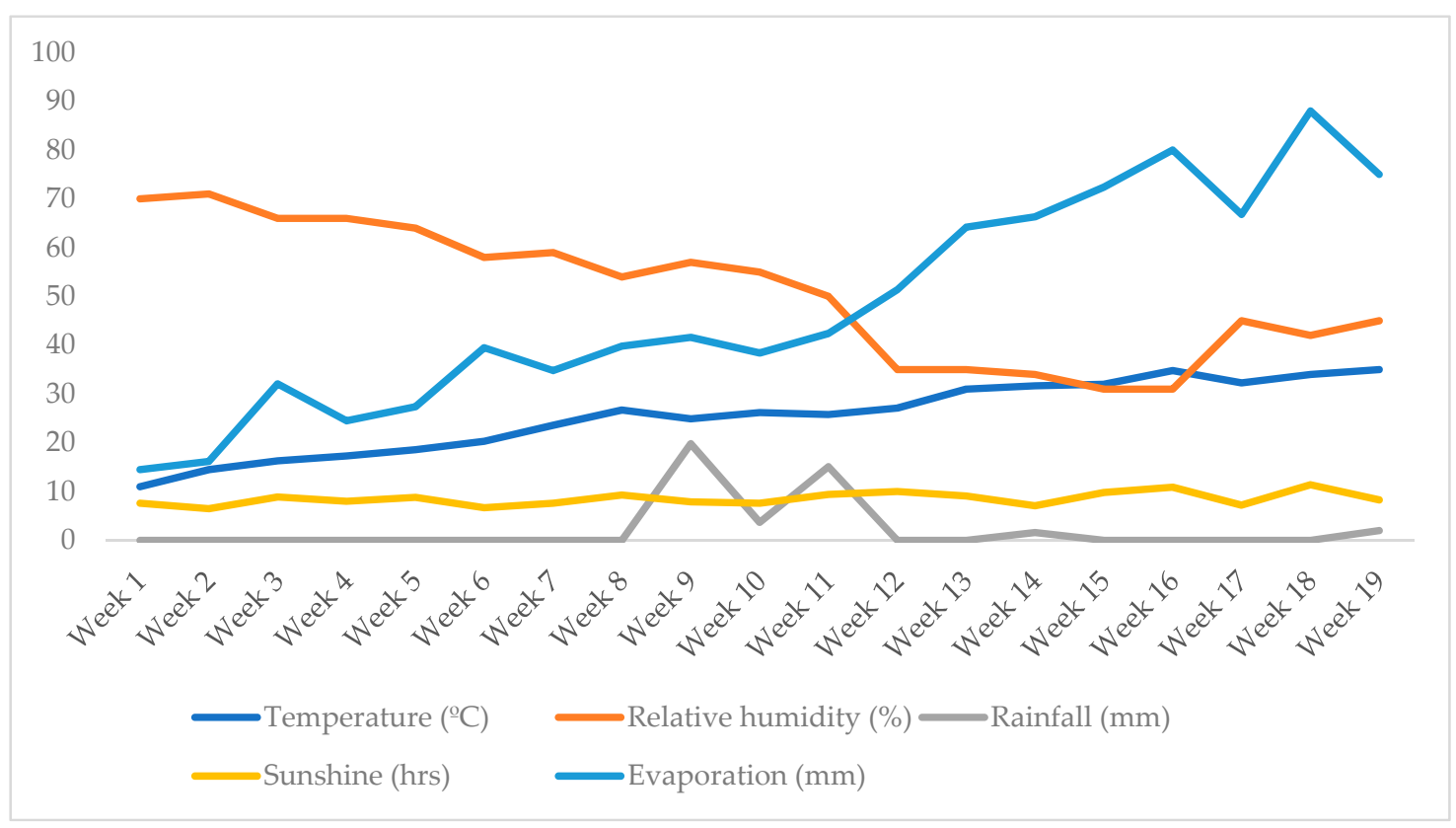

(B)

Figure 4. Weather parameters during first (A) and second (B) year.

Physical properties of soil were also analyzed to determine the native fertility and soil texture of the experimental fields (Table 6). The composite soil samples were collected from the topsoil layer 
$(0-15 \mathrm{~cm})$ of the experimental site and analyzed for sand, silt clay content and soil temperature using the methods defined elsewhere [67].

Table 6. Soil physical properties of experimental site.

\begin{tabular}{cc}
\hline Soil Property & Value \\
\hline Sand (per cent) & 82.2 \\
Silt (per cent) & 7.1 \\
Clay (per cent) & 10.7 \\
Textural class & loamy sand \\
Soil temperature (mean) & $13^{\circ} \mathrm{C}$ \\
\hline
\end{tabular}

\subsection{Characterization of Plants and Data Analysis}

Five central plants per plot (i.e., ten plants per replication) were used for the data acquisition and characterization. The number of leaves per plant was determined as the average of plant leaves at the time of maturity. The leaf area $\left(\mathrm{m}^{2}\right)$ was calculated using an area meter (LI-3100; LICOR, Lincoln, NE, USA). Whereas, the specific leaf weight ( $\mathrm{g}$ ) was estimated as total leaf weight divided by the number of leaves. The leaf area index $(\mathrm{LAI})$ was estimated using the formula, $\mathrm{LAI}=(\mathrm{A} \times \mathrm{N}) / 10,000$, where $\mathrm{A}$ is leaf area $\left(\mathrm{cm}^{2}\right)$ and $\mathrm{N}$ is plants per $\mathrm{m}^{2}$ [68]. The leaf water potential in Mega-Pascal's (MPa) was recorded with the help of vapour pressure osmometer (Wescor Vapro 5520, Wescor Inc. Logan, UT, USA). The relative leaf water content (RLWC) was determined based on the formula, RLWC $=100 \times$ (Fresh weight - Dry weight/Saturated weight - Dry weight) [69]. The chlorophyll content of leaves was recorded as a SPAD meter reading with the help of soil plant analysis development (SPAD meter) (SPAD 502 Plus Chlorophyll Meter, Minolta, Japan) [70]. The proline content (mg/g dry weight of leaf), was estimated based on the method defined elsewhere [71]. The biological yield (g/plant) was calculated as the above-ground weight of total plant including the sunflower head. Whereas, the harvest index $(\mathrm{HI})$ was estimated based on the formula, $\mathrm{HI}=100 \times$ seed yield/total biomass (vegetative mass (VM) + Seed Yield) at maturity [72]. Furthermore, to determine the seed yield the harvested seeds from five competitive plants were weighed and averaged. Oil content (\%) was estimated using the nuclear magnetic resonance (NMR) analyzer (Newport Analyzer MK III A, Newport Instruments Ltd., Milton Keynes, England) [73].

The replicated data for all the descriptors across the period of two years was subjected to the statistical analysis. The popular (Unweighted Pair Group Method with Arithmetic Mean) UPGMA method of hierarchical clustering was used to visualize how parental genotypes are related based on the differences in the data of twelve descriptors using the R platform (R Core Team 2015). The "average" method was used with the function hclust [74]. The Line $\times$ Tester calculations were performed following standard procedures for the estimation of components of genetic variation, with the help of the SAS software, version 9.1.SAS Institute, Inc. SAS user's guide. Version 9, 4th ed. Cary, NC. 2004 [32]. While the Pearson correlation coefficients were determined and plotted via packages corrplot and Performance Analytics [75,76]. All the other remaining statistical analysis were carried out using the Statgraphics Centurion XVIII software package (version 18, StatPoint Technologies, Warrenton, VA, USA).

\section{Conclusions}

The accession CMS-234A was the best general combiner for biological yield and photosynthetic efficiency under both the conditions. The cross combinations CMS-ARG-2A $\times$ RCR-8297, CMS-234A $\times$ P124R, and CMS-38A $\times$ P124R were found significant for biological yield, seed yield and oil content under both environments. Similarly, ARG-6A $\times$ P124R recorded maximum significant SCA effects for the number of leaves/plants. The hybrids CMS-ARG-2A $\times$ RCR-8297 and CMS-234A $\times$ P100R recorded highly significant SCA effects for leaf area, specific leaf weight and leaf area index under both the environments. For proline content two hybrids i.e., CMS-XA $\times$ P69R and 
CMS-ARG-2A $\times$ P124R shown the higher SCA effects under both the environments. The hybrids PRUN-29A $\times$ P69R and 234A $\times$ P69R recorded high SCA effects for biological yield/plant under both the environments. The parents (female and male) generally had high GCA (good combiners) for both the environments. Therefore, they can be exploited in the hybrid development program for drought tolerance, high yielding, and physiologically efficient with a diverse cytoplasmic background. All in all, the information about different cytoplasmic sources and their effect on traits under water-limited environment will be useful for the development of new hybrids adapted to the challenges imposed by the drought.

Supplementary Materials: Supplementary materials can be found at http:/ /www.mdpi.com/2073-4395/8/ 10/232/s1. Table S1: Data of specific combining ability of sixty one-way $\mathrm{F}_{1}$ hybrids under normal and water stress environment.

Author Contributions: V.T. and S.K.D. conceived of and designed the project. S.K.D. supervised the study. V.T. G.K. and P.K. performed the experiments. V.T., P.K. and G.K. analyzed the data. P.K. and V.T. wrote the paper and corrected the final draft. All authors read and approved the final manuscript.

Acknowledgments: The authors are thankful to the anonymous reviewers for their careful reading of the manuscript and providing the insightful suggestions.

Conflicts of Interest: The authors declare no conflict of interest.

\section{Abbreviations}

A Cytoplasmic male sterile line

B Maintainer line

CMS Cytoplasmic male sterile

$\mathrm{GA}_{3} \quad$ Gibberellic acid

GCA General combining ability

HI Harvest index

LAI Leaf area index

$\mathrm{R} \quad$ Restorer line

RCBD Randomized complete block design

RLWC Relative leaf water content

SCA Specific combining ability

\section{References}

1. Pal, D. Sunflower (Helianthus annuus L.) Seeds in Health and Nutrition-Chapter 130. In Nuts and Seeds in Health and Disease Prevention; Preedy, V.R., Watson, R.R., Patel, V.B., Eds.; Academic Press: San Diego, CA, USA, 2011; pp. 1097-1105, ISBN 978-0-12-375688-6.

2. González-Alonso, A.; Ramírez-Tortosa, C.; Varela-López, A.; Roche, E.; Arribas, M.; Ramírez-Tortosa, M.; Giampieri, F.; Ochoa, J.; Quiles, J.; González-Alonso, A.; et al. Sunflower Oil but Not Fish Oil Resembles Positive Effects of Virgin Olive Oil on Aged Pancreas after Life-Long Coenzyme Q Addition. Int. J. Mol. Sci. 2015, 16, 23425-23445. [CrossRef] [PubMed]

3. Gandhi, S.D.; Heesacker, A.F.; Freeman, C.A.; Argyris, J.; Bradford, K.; Knapp, S.J. The self-incompatibility locus (S) and quantitative trait loci for self-pollination and seed dormancy in sunflower. Theoret. Appl. Genet. 2005, 111, 619-629. [CrossRef] [PubMed]

4. Lai, Z.; Nakazato, T.; Salmaso, M.; Burke, J.M.; Tang, S.; Knapp, S.J.; Rieseberg, L.H. Extensive Chromosomal Repatterning and the Evolution of Sterility Barriers in Hybrid Sunflower Species. Genetics 2005, 171, 291-303. [CrossRef] [PubMed]

5. Khatun, M.; Hossain, T.M.; Miah, M.M.; Khandoker, S.; Rashid, M.A. Profitability of sunflower cultivation in some selected sites of Bangladesh. Bangladesh J. Agric. Res. 2016, 41, 599-623. [CrossRef]

6. Sheoran, P.; Sheoran, O.P.; Sardana, V. Modeling Sunflower Productivity and Profitability in Relation to Adequate and Limited Sulphur Availability under Semiarid Irrigated Conditions. Int. J. Agron. 2013, 2013, 738263. Available online: https:/ /www.hindawi.com/journals/ija/2013/738263/ (accessed on 20 August 2018). [CrossRef] 
7. Dimitrijevic, A.; Horn, R. Sunflower Hybrid Breeding: From Markers to Genomic Selection. Front. Plant Sci. 2018, 8, 2238. [CrossRef] [PubMed]

8. Bohra, A.; Jha, U.C.; Adhimoolam, P.; Bisht, D.; Singh, N.P. Cytoplasmic male sterility (CMS) in hybrid breeding in field crops. Plant Cell Rep. 2016, 35, 967-993. [CrossRef] [PubMed]

9. Jansky, S. Breeding, Genetics, and Cultivar Development-Chapter 2. In Advances in Potato Chemistry and Technology; Singh, J., Kaur, L., Eds.; Academic Press: San Diego, CA, USA, 2009; pp. 27-62, ISBN 978-0-12-374349-7.

10. Griffiths, A.J.; Miller, J.H.; Suzuki, D.T.; Lewontin, R.C.; Gelbart, W.M. Cytoplasmic male sterility. In $A n$ Introduction to Genetic Analysis, 7th ed.; W.H. Freeman and Company: San Francisco, CA, USA, 2000.

11. Leclercq, P. Une sterilite male cytoplasmique chez le tournesol. Ann. Amel. Plantes 1969, 19, 99-106.

12. Leclercq, P.; Philippon, J.P. Identification de gènes de restauration de fertilité sur cytoplasmes stérilisants chez le tournesol. Agronomie 1984, 4, 573-576. [CrossRef]

13. Horn, R.; Gupta, K.J.; Colombo, N. Mitochondrion role in molecular basis of cytoplasmic male sterility. Mitochondrion 2014, 19 Pt B, 198-205. [CrossRef]

14. Echeverria, M.M.; Salaberry, M.T.; Rodriguez, R.H. Characterization for agronomic use of cytoplasmic male-sterility in sunflower (Helianthus annuus L.) introduced from H. resinosus Small. Plant Breed. 2003, 122, 357-361. [CrossRef]

15. Owens, G.L.; Baute, G.J.; Hubner, S.; Rieseberg, L.H. Genomic sequence and copy number evolution during hybrid crop development in sunflowers. Evol. Appl. 2018. [CrossRef]

16. Salehi-Lisar, S.Y.; Bakhshayeshan-Agdam, H. Drought Stress in Plants: Causes, Consequences, and Tolerance. In Drought Stress Tolerance in Plants; Springer: Cham, Switzerland, 2016; Volume 1, pp. 1-16, ISBN 978-3-319-28897-0.

17. Kaya, Y.; Pekcan, V.; Cicek, N. Effects of Drought on Morphological Traits of some Sunflower Lines. Ekin J. 2016, 2, 54-68.

18. Prasad, P.V.V.; Staggenborg, S.; Ristic, Z.; Ahuja, L.; Reddy, V.; Anapalli, S.; Yu, Q. Impacts of Drought and/or Heat Stress on Physiological, Developmental, Growth, and Yield Processes of Crop Plants; American Society of Agronomy, Crop Science Society of America, Soil Science Society of America: Madison, WI, USA, 2008.

19. Pekcan, V.; Evci, G.; Ibrahim Yilmaz, M.; Balkan Nalçaiyi, S.; Çulha Erdal, Ş.; Çiçek, N.; Ekmekci, Y.; Kaya, Y. Drought effects on yield traits of some sunflower inbred lines. Podgorica 2015, 61, 101. [CrossRef]

20. Seiler, G.J.; Qi, L.L.; Marek, L. Use of Sunflower Crop Wild Relatives for Cultivated Sunflower Improvement. Crop Sci. 2017, 57, 1083-1101. [CrossRef]

21. Vukich, M.; Schulman, A.H.; Giordani, T.; Natali, L.; Kalendar, R.; Cavallini, A. Genetic variability in sunflower (Helianthus annuus L.) and in the Helianthus genus as assessed by retrotransposon-based molecular markers. Theoret. Appl. Genet. 2009, 119, 1027-1038. [CrossRef] [PubMed]

22. Darvishzadeh, R.; Pirzad, A.; Bernousi, I.; Mandoulakani, B.A.; Azizi, H.; Akhondi, N.; Kiani, S.P.; Sarrafi, A. Genetic properties of drought tolerance indices in sunflower. Acta Agric. Scand. B Soil Plant 2011, 61, 593-601. [CrossRef]

23. Rauf, S. Breeding sunflower (Helianthus annuus L.) for drought tolerance. Commun. Biometry Crop Sci. 2008, 3, $29-44$.

24. Cechin, I.; Rossi, S.C.; Oliveira, V.C.; Fumis, T.F. Photosynthetic responses and proline content of mature and young leaves of sunflower plants under water deficit. Photosynthetica 2006, 44, 143-146. [CrossRef]

25. Levings, C.S. The Texas cytoplasm of maize: Cytoplasmic male sterility and disease susceptibility. Science 1990, 250, 942-947. [CrossRef] [PubMed]

26. Miller, R.J.; Koeppe, D.E. Southern corn leaf blight: Susceptible and resistant mitochondria. Science 1971, 173, 67-69. [CrossRef] [PubMed]

27. Reddemann, A.; Horn, R.; Reddemann, A.; Horn, R. Recombination Events Involving the atp9 Gene Are Associated with Male Sterility of CMS PET2 in Sunflower. Int. J. Mol. Sci. 2018, 19, 806. [CrossRef] [PubMed]

28. Jan, C.C. Cytoplasmic Male Sterility in Two Wild Helianthus annuus L. Accessions and Their Fertility Restoration. Crop Sci. 2000, 40, 1535-1538. [CrossRef]

29. Tyagi, V.; Dhillon, S. Effect of Alien Cytoplasm on Combining Ability for Earliness and Seed Yield in Sunflower under Irrigation and Drought Stress. Helia 2017, 40, 71-83. [CrossRef]

30. Horn, R. Molecular diversity of male sterility inducing and male-fertile cytoplasms in the genus Helianthus. Theor. Appl. Genet. 2002, 104, 562-570. [CrossRef] [PubMed] 
31. Fujino, Y.; Murata, H.; Mayama, C.; Asaoka, R. A Review on Mating Designs. Nat. Sci. 2015, 13, $98-105$.

32. Clark, P.J.; Kempthorne, O. An Introduction to Genetic Statistics; John Wiley \& Sons, Inc.: New York, NY, USA, 1958; Volume 39, p. 313.

33. Numerical Ecology, Volume 24-2nd Edition. Available online: https://www.elsevier.com/books/ numerical-ecology/legendre/978-0-444-89249-2 (accessed on 15 July 2018).

34. Khan, A.; Sovero, V.; Gemenet, D. Genome-assisted Breeding for Drought Resistance. Curr. Genom. 2016, 17, 330-342. [CrossRef] [PubMed]

35. Zhang, H.; Mittal, N.; Leamy, L.J.; Barazani, O.; Song, B. Back into the wild-Apply untapped genetic diversity of wild relatives for crop improvement. Evol. Appl. 2016, 10, 5-24. [CrossRef] [PubMed]

36. Ford-Lloyd, B.V.; Schmidt, M.; Armstrong, S.J.; Barazani, O.; Engels, J.; Hadas, R.; Hammer, K.; Kell, S.P.; Kang, D.; Khoshbakht, K.; et al. Crop Wild Relatives-Undervalued, Underused and under Threat? BioScience 2011, 61, 559-565. [CrossRef]

37. Budak, H.; Kantar, M.; Yucebilgili, K.K. Drought Tolerance in Modern and Wild Wheat. Sci. World J. 2013, 2013, 548246. [CrossRef] [PubMed]

38. Kumar, A.; Dixit, S.; Ram, T.; Yadaw, R.B.; Mishra, K.K.; Mandal, N.P. Breeding high-yielding drought-tolerant rice: Genetic variations and conventional and molecular approaches. J. Exp. Bot. 2014, 65, 6265-6278. [CrossRef] [PubMed]

39. Škorić, D. Sunflower Breeding for Resistance to Abiotic and Biotic Stresses. In Abiotic and Biotic Stress in Plants—Recent Advances and Future Perspectives; InTech: Rijeka, Croatia, 2016.

40. Seiler, G.J. Wild annual Helianthus anomalus and H. deserticola for improving oil content and quality in sunflower. Ind. Crops Prod. 2007, 25, 95-100. [CrossRef]

41. Hussain, M.M.; Rauf, S.; Riaz, M.A.; Al-Khayri, J.M.; Monneveux, P. Determination of drought tolerance related traits in Helianthus argophyllus, Helianthus annuus, and their hybrids. Breed. Sci. 2017, 67, 257-267. [CrossRef] [PubMed]

42. Joseph, B.; Corwin, J.A.; Züst, T.; Li, B.; Iravani, M.; Schaepman-Strub, G.; Turnbull, L.A.; Kliebenstein, D.J. Hierarchical Nuclear and Cytoplasmic Genetic Architectures for Plant Growth and Defense within Arabidopsis. Plant Cell 2013, 25, 1929-1945. [CrossRef] [PubMed]

43. Zhang, X.; Lu, G.; Long, W.; Zou, X.; Li, F.; Nishio, T. Recent progress in drought and salt tolerance studies in Brassica crops. Breed. Sci. 2014, 64, 60-73. [CrossRef] [PubMed]

44. Sanetomo, R.; Gebhardt, C. Cytoplasmic genome types of European potatoes and their effects on complex agronomic traits. BMC Plant Biol. 2015, 15, 162. [CrossRef] [PubMed]

45. Beavis, W.D.; Pollak, E.; Frey, K.J. A theoretical model for quantitatively inherited traits influenced by nuclear-cytoplasmic interactions. Theoret. Appl. Genet. 1987, 74, 571-578. [CrossRef] [PubMed]

46. Yu, G.; Xiang, H.; Tian, J.; Yin, J.; Pinkert, C.A.; Li, Q.; Zhao, X. Mitochondrial Haplotypes Influence Metabolic Traits in Porcine Transmitochondrial Cybrids. Sci. Rep. 2015, 5, 13118. [CrossRef] [PubMed]

47. Kaushik, P.; Dhaliwal, M.S. Diallel Analysis for Morphological and Biochemical Traits in Tomato Cultivated under the Influence of Tomato Leaf Curl Virus. Agronomy 2018, 8, 153. [CrossRef]

48. Putt, E.D. Heterosis, Combining Ability, and Predicted Synthetics from a Diallel Cross in Sunflowers (Helianthus annuus L.). Can. J. Plant Sci. 1966, 46, 59-67. [CrossRef]

49. Giriraj, K.; Hiremath, S.R.; Seenappa, K. Combining ability of converted male sterile lines of sunflower (Helianthus annuus L.). Indian J. Genet. Plant Breed. 1987, 47, 315-317.

50. Hladni, N.; Jocić, S.; Miklič, V.; Mijić, A.; Saftić-Panković, D.; Škorić, D. Effect of morphological and physiological traits on seed yield and oil content in sunflower. Helia 2014, 33, 101-116. [CrossRef]

51. Dudhe, M.Y.; Moon, M.K.; Lande, S.S. Study of gene action for restorer lines in sunflower. Helia 2014, 34, 159-164. [CrossRef]

52. Golabadi, M.; Golkar, P.; Shahsavari, M.R. Genetic analysis of agro-morphological traits in promising hybrids of sunflower (Helianthus annuus L.). Acta Agric. Slov. 2015, 105, 249-260. [CrossRef]

53. Jocić, S.; Cvejić, S.; Ciric, M.; Hladni, N.; Miladinović, D.; Miklic, V. Estimation of combining abilities in sunflower (Helianthus annuus L.). In Proceedings of the 18th International Sunflower Conference, Mar del Plata, Argentina, 27 February-1 March 2012; pp. 657-662.

54. Salem, A.H.; Ali, M.A. Combining ability for sunflower yield contributing characters and oil content over different water supply environments. J. Am. Sci. 2012, 8, 230-237. 
55. Kaya, Y.; Atakisi, I.K. Combining ability analysis of some yield characters of sunflower (Helianthus annuus L.). Helia 2004, 41, 75-84. [CrossRef]

56. Andarkhor, S.A.; Mastibege, N.; Rameeh, V. Combining ability of agronomic traits in Sunflower (Helianthus annuus L.) using line $\mathrm{X}$ tester analysis. Int. J. Biol. 2011, 4, 89-95. [CrossRef]

57. Mirarab, M.; Ahmadikhah, A. Study on genetics of some important phonological traits in rice using line $\times$ tester analysis. Ann. Biol. Res. 2010, 4, 119-125.

58. Kang, S.A.; Khan, F.A.; Ahsan, M.Z.; Chatha, W.S.; Saeed, F. Estimation of combining ability for the development of hybrid genotypes in sunflower (Helianthus annuus L.). J. Biol. Agric. Healthc. 2013, 39, 68-74.

59. Memon, S.; Baloch, M.J.; Baloch, G.M.; Jatoi, W.A. Combining ability through line $\times$ tester analysis for phenological, seed yield, and oil traits in sunflower (Helianthus annuus L.). Euphytica 2015, 204, 199-209. [CrossRef]

60. Kadkol, G.P.; Anand, I.J.; Sharma, R.P. Combining ability and heterosis in sunflower. Indian J. Genet. Plant Breed. 1984, 44, 447-451.

61. Andarkhor, S.A.; Rameeh, V.; Alitabar, R.A. Estimation of genetic parameters for yield components and seed yield in sunflower using line x tester analysis. Afr. J. Biotechnol. 2013, 12, 3978-3983.

62. Karasu, A.; Mehmet, O.Z.; Sincik, M.; Goksoy, A.T.; Turan, Z.M. Combining ability and heterosis for yield and yield components in sunflower. Not. Bot. Horti Agrobot. Cluj Napoca 2010, 38, 259-264.

63. Pace, B.A.; Alexander, H.M.; Emry, J.D.; Mercer, K.L. Seed fates in crop-wild hybrid sunflower: Crop allele and maternal effects. Evol. Appl. 2015, 8, 121-132. [CrossRef] [PubMed]

64. Seetharam, A.; Kumari, P.K. Induction of male sterility by gibberellic acid in sunflower. Indian J. Genet. Plant Breed. 1975, 35, 136-138.

65. Baydar, H.; Gökmen, O.Y.; Friedt, W. Hybrid seed production in safflower (Carthamus tinctorius) following the induction of male sterility by gibberellic acid. Plant Breed. 2003, 122, 459-461. [CrossRef]

66. Razzaq, H.; Tahir, N.; Hammad, M.; Ahmad Sadaqat, H.; Sadia, B. Screening of sunflower (Helianthus annus L.) accessions under drought stress conditions, an experimental assay. J. Soil Sci. Plant Nutr. 2017, 17, 662-671. [CrossRef]

67. Bandyopadhyay, K.; Aggarwal, P.; Chakraborty, D.; Pradhan, S.; Narayan Garg, R.; Singh, R. Practical Manual on Measurement of Soil Physical Properties Practical; Indian Agricultural Research Institute: New Delhi, India, 2012; pp. 8-25.

68. Maldaner, I.C.; Heldwein, A.B.; Loose, L.H.; Lucas, D.D.P.; Guse, F.I.; Bortoluzzi, M.P. Modelos de determinação não-destrutiva da área foliar em girassol. Cienc. Rural 2009, 39, 1356-1361. [CrossRef]

69. Smart, R.E.; Bingham, G.E. Rapid Estimates of Relative Water Content. Plant Physiol. 1974, 53, $258-260$. [CrossRef] [PubMed]

70. Ling, Q.; Huang, W.; Jarvis, P. Use of a SPAD-502 meter to measure leaf chlorophyll concentration in Arabidopsis thaliana. Photosynth. Res. 2011, 107, 209-214. [CrossRef] [PubMed]

71. Bates, L.S.; Waldren, R.P.; Teare, I.D. Rapid determination of free proline for water-stress studies. Plant Soil 1973, 39, 205-207. [CrossRef]

72. Wnuk, A.; Górny, A.; Bocianowski, J.; Kozak, M. Visualizing harvest index in crops. Commun. Biometry Crop Sci. 2013, 8, 48-59.

73. Robertson, J.A.; Morrison, W.H. Analysis of oil content of sunflower seed by wide-line NMR. J. Am. Oil Chem. Soc. 1979, 56, 961-964. [CrossRef]

74. Esteves, F. R Script for UPGMA Analysis. Available online: https:/ / www.researchgate.net/publication/ 303944638_R_script_for_Principal_Component_Analysis_PCA (accessed on 15 July 2018).

75. Wei, T.; Simko, V.; Levy, M.; Xie, Y.; Jin, Y.; Zemla, J. Corrplot: Visualization of a Correlation Matrix. 2017. Available online: http:/ / cran.r-project.org/package=corrplot (accessed on 2 August 2018).

76. Peterson, B.G.; Carl, P.; Boudt, K.; Bennett, R.; Ulrich, J.; Zivot, E.; Cornilly, D.; Hung, E.; Lestel, M.; Balkissoon, K.; et al. Performance Analytics: Econometric Tools for Performance and Risk Analysis. 2018. Available online: https:/ /github.com/braverock/PerformanceAnalytics (accessed on 2 August 2018).

(C) 2018 by the authors. Licensee MDPI, Basel, Switzerland. This article is an open access article distributed under the terms and conditions of the Creative Commons Attribution (CC BY) license (http://creativecommons.org/licenses/by/4.0/). 